\title{
A risk management perspective on CSR and the marginal cost of debt: empirical evidence from Europe
}

\section{Othar Kordsachia ${ }^{1}$}

Received: 23 April 2019 / Accepted: 14 April 2020 / Published online: 30 April 2020

(C) The Author(s) 2020

\begin{abstract}
This article investigates the association between CSR and marginal credit costs of European companies. We provide instance for a negative association based on a variety of model specifications and fine-grained measures for CSR. These results can be explained in light of the increasing relevance of socially responsible investors for financing costs of companies. We further apply the risk management perspective on CSR to the credit market and show that the insurance-like property of CSR is especially relevant for companies in relative financial distress as measured by the interest coverage ratio. This study also examines the association between CSR assurance and credit costs and provides evidence that creditors reward non-financial insurance by reduced required rate of returns. Finally, we contribute to the corporate governance literature by modelling the association between different board characteristics and credit costs.
\end{abstract}

Keywords Cost of debt - Corporate social responsibility · Corporate governance · Risk mitigation

JEL Classification M14 · G30

\section{Introduction}

Intensified by the recent financial crisis of 2008/09, the concept of corporate social responsibility (CSR) is increasingly important for modern business and society in Europe (European Commission 2014a; Kudłak et al. 2018). A wide array of stakeholders now closely monitors CSR activities of companies and adjust their contribution of financial and social capital accordingly (Choi and Wang 2009; Servaes and Tamayo 2013; Ioannou and Serafeim 2015; Dyck et al. 2019). Reflective of

Othar Kordsachia

othar.kordsachia@uni-hamburg.de

1 Department of Socioeconomics, Faculty of Business, Economics and Social Sciences,

University of Hamburg, Renzelstraße 7, 20146 Hamburg, Germany 
this development, the European Commission (2018) recommends that also credit rating agencies and financial institutions conduct long-term risk analysis, which includes the consideration of environmental-, social-, and governmental (ESG) factors. Likewise, The United Nations-supported Principles for Responsible Investment (PRI) discusses the shifting perceptions of fixed-income investors and credit rating agencies progressively including ESG performance in credit risk analysis ('Credit Ratings Initiative'; PRI 2017, 2018). Moreover, the trajectory towards the transparent and systematic integration of ESG risks into credit decisions is also endorsed and accelerated by other prominent risk management- and reporting frameworks (O'Sullivan and O'Dwyer 2009; Macve and Chen 2010; O'Sullivan and O'Dwyer 2015; Weber 2018). In particular, financial institutions who voluntarily adopt the Equator Principles pledge to "identify, assess and manage environmental and social risks and impacts in a structured way, on an ongoing basis" (Equator Principles 2013, p.2). Accordingly, some of the largest and most prominent European banks are committed to disclosing how their credit decisions and business practices align to ESG-specific matters (Chava 2014).

The trend towards investment decisions based on non-financial information, commonly operationalized through positive or negative screening procedures, is, however, certainly not limited to financial institutions (Dyck et al. 2019; Gangi and Varrone 2018). The dramatic increase of the economic relevance of other socially responsible investors over the past decade (Belghitar et al. 2014; Majoch et al. 2017) is evidenced by an upsurge of the number of signatories (investment managers, asset owners and service providers) of the PRI from 734 in 2010 to 1961 in 2018. Over the same timeframe the assets under management increased from 21.0 to 81.7 Trillion (USD). By signing the PRI, large and systemically relevant institutional investors pledge to incorporate ESG considerations into their investment decisions and agree to publish annual transparency reports outlining their individual implementation of socially responsible investing (SRI).

There is also a trend to towards SRI of morally (or ethically) motivated private investors (Riedl and Smeets 2017; Gasser et al. 2017). Over the past decade, the adoption of voluntary reporting frameworks regarding the disclosure of non-financial performance (Willis 2003; Brown et al. 2009) proliferated the accessibility of ESG performance indicators of companies for these investors. In this context, the increasing importance of CSR reporting for socially responsible investors in Europe is also elucidated by the extension of the management report by the amending directive 2014/95/EU as regards the disclosure of non-financial and diversity information by certain large undertakings and groups (European Commission 2014b; CSR Europe and GRI 2017). Based on their increasing access to non-financial information and due to the proliferation of ESG bond funds (Derwall and Koedijk 2009; Amey and Power 2018), not only large institutional investors and banks, but also socially responsible private investors may now have an impact on companies' credit costs through CSR screenings as part of their lending decisions.

Coinstantaneous and even prior to these developments, an avalanche of research on the value relevance of CSR activities emerged (for meta-analyses see; Orlitzky et al. 2003; Margolis et al. 2009; Wang et al. 2016; Busch and Friede 2018). Yet, these studies are predominantly equity-based and, by comparison, very little is 
known about the credit market in this context (Gong et al. 2018). In fact, "it has only been in the last few years that some attention has been paid on the possibility of a linkage between CSR and cost of debt" (Hoepner et al. 2016, p. 160). Previous research provides mixed results, and this negligently ignored research stream (Stellner et al. 2015), is subject to number of issues, which impede comparability between extant studies as well as meaningful conclusions that could enhance managerial decision-making regarding CSR-related business strategies. In particular, results differ due to the various measurements for credit costs, ${ }^{1}$ which are also mostly retrospective (except Sharfman and Fernando (2008), who use "the firm's marginal cost of borrowing based on estimates derived from the from the Bloomberg Financial dataset" (p. 576)). Moreover, the operationalization of CSR as the main explanatory variable varies greatly regarding (i) its focus on performance versus disclosure ${ }^{2}$ as well as (ii) its scope in terms of environmental, social, or governmental factors. ${ }^{3}$

This article's objective is to address these issues while theoretically arguing and empirically testing for a negative linear association between CSR and the marginal cost of issuing additional debt (COD). In order to widen the scope of our analysis, we also investigate the moderating impact of financial distress, the relevance of CSR assurance (CSRA) and the impact various board characteristics in this context.

Contributing to the literature on CSR disclosure and the cost of debt (e.g. Gong et al. 2018), we examine the impact of CSRA on credit costs. Strikingly, previous research on this topic is exclusively equity based. The assurance of sustainability information safeguards the veracity and transparency of the CSR report. Report addressees may therefore trust the provided information and adjust their financial and social capital accordingly.

In response to earlier studies pointing to the relevance of specific board characteristics for credit costs (e.g. Oikonomou et al. 2014; Bradley and Chen 2015; Stellner et al. 2015), we analyze those separately in subsequent analysis. Corporate governance characteristics are an important factor in determining a company' business strategy and can therefore have a major influence on credit decisions. In particular, the company board has the task of monitoring management actions and balancing the legitimate needs of various stakeholders. As such, they are also responsible for building and maintaining creditor relationships and reducing agency costs.

Our results show that CSR is negatively associated with COD. This finding is robust over a variety of different measurements of CSR and statistical estimation techniques. We further theoretically derive and empirically show the moderating impact of a firm's financial situation. The negative impact of better ESG

\footnotetext{
1 Commonly used measurements are the ratio of interest expense to interest-bearing debt (Ye and Zhang 2011; Jung et al. 2018; La Rosa et al. 2018), credit ratings (Oikonomou et al. 2014; Stellner et al. 2015; La Rosa et al. 2018), bond yield spreads (Menz 2010; Gong et al. 2018), and loan agreements (Chava 2014; Goss and Roberts 2011; Kim et al. 2014; Hoepner et al. 2016).

2 For example, Gong et al. (2018) focus on CSR disclosure, whereas Menz (2010) and Oikonomou et al. (2014) examine CSR Performance.

3 For example, some studies focus only on the environmental performance of companies (Sharfman and Fernando 2008; Chava 2014), social performance (La Rosa et al. 2018), ethical behavior (Kim et al. 2014), or charitable donations (Ye and Zhang 2011).
} 
performance on COD is stronger for companies with low interest coverage ratios. In line with our expectations, we find that CSRA significantly lowers COD, which is likely the manifestation of lower information asymmetries between managers and bondholders. Finally, we find that, indeed, several board characteristics have a statistically and economically significant impact on COD. In particular, our results indicate that board independence, board size, and board gender diversity are negatively associated with the COD. We find an opposite association with regard to board specific skills and no significant results regarding average board tenure. Thus, this study not only responds to the increasing regulatory interest on the impact of ESG-performance on the credit market ('Credit Ratings Initiative'; PRI 2017, 2018; European Commission 2018), but also advances the inconclusive and narrow scientific literature on this matter in an important way.

In particular, this study contributes to our understanding about the interplay between CSR, corporate governance, and the European credit market. We consistently find evidence that complex and economically meaningful interdependencies exist. Managers can build upon these findings and take specific actions to optimize their firms' position at the credit market. Exemplarily, our findings strongly suggest that CSR investments during times of firms' superior financial performance can facilitate investor trust in terms of moral goodwill, and, as a result, lead to lower credit costs during times of greater financial distress. This finding corroborates earlier landmark studies that were based on the analysis of the equity market (Godfrey et al. 2009; Lins et al. 2017). This study is also relevant in light of the European Commission's regulatory focus on sustainable finance. In line with the Non-Financial Reporting Directive (European Commission 2014b), companies are encouraged to disclose economic activities that meet the proposed EU taxonomy criteria in order to be eligible for environmentally oriented equity and debt funds (European Commission 2020). In this context, our findings principally support the notion that granular non-financial information disclosure is economically relevant for fixed-income investors, such as insurance companies and pension funds.

\section{Related literature}

Previous research predominantly focuses on the association between CSR and shareholder value, providing largely conflicting results ${ }^{4}$ based on opposing theoretical foundations. The traditional perspective posits that "only people have

\footnotetext{
4 There is a considerate research density with over 200 studies on this association (Montiel and DelgadoCeballos 2014). Contradictory findings find a positive relation, negative relation, U-shaped and even an inverse U-shaped relation (McWilliams and Siegel 2000; Margolis and Walsh 2003; Margolis et al. 2009). Recent studies conclude that the extant literature is inconclusive with no clear scientific consensus. Yet, newer studies increasingly support an overall positive relation based on the institutional stakeholder perspective, particularly for companies whose CSR activities are perceived to be credible and are not merely utilized as a marketing tool. This development could be due to shifting institutional logics, where the emergence of a stakeholder focus causes that CSR is less perceived as an agency cost and that CSR firms are analyzed more optimistically over time (Ioannou and Serafeim 2015).
} 
responsibilities" and that the mere purpose of corporations is to increase profits (Friedman 1970, p. 1). In that sense, CSR investments would represent an expensive diversion of scarce resources (Goss and Roberts 2011). Corporate philanthropy, as a manifestation of CSR (Godfrey 2005), would generally be detrimental to shareholder wealth maximization due to an economic disadvantage compared to less socially responsible companies. There is wide array of CSR expenditures that can relate to a multitude of socio-economic matters within a company's scope of impact. Exemplary, these can take the form of charitable contributions, community development activities, environmental expenditures, and audits fees due to the assurance of non-financial information. Some researchers argue that these expenditures represent agency costs that arise due to managerial overinvestments for private gains at the expense of shareholders (Harjoto and Jo 2011). A related issue is that a CSR firm could be limited in its strategic market positioning because it has to refrain from investing in certain product lines, for example due to carbon dioxide intensive production or hazardous waste products. Ethical concerns may prevent a CSR firm from entering a potentially profitable industry (e.g. genetic engineering). Likewise, investment opportunities in certain locations (e.g. Saudi Arabia) could not be realized due to human rights violations, corruption or other country-specific concerns (McGuire et al. 1988).

In contrast, other researchers assume a positive impact of CSR by providing better access to valuable resources (Udayasankar 2008) due to several factors, such as superior recruitment of quality employees, greater customer goodwill, better brand reputation, and gaining social legitimacy (Weber 2008; Zhao 2012; Hur et al. 2014). Likewise, CSR can improve the access to financial resources from SR investors (Cheng et al. 2014), who are morally motivated (Riedl and Smeets 2017) and derive value in terms of a 'psychic dividend' (Auer and Schuhmacher 2016; Ainsworth et al. 2018). Advocates for CSR also argue that these activities should best be analyzed from a risk management perspective. Accordingly, responsible behavior can build up moral capital or goodwill that has an insurance-like property to mitigate the financial impact of unforeseen negative events (Godfrey 2005).

Due to diverging interests of shareholders and creditors (Chow 1982) and because debt markets perceive risks differently than equity markets (Sharfman and Fernando 2008; Dhaliwal et al. 2011) we propose that studies on the relation between CSR and the cost of debt should be analyzed separately from the vast amount equity-based research. Despite the relevance of the credit market, especially in Europe (European Commission 2017), few studies examine this association and extant studies provide controversial and conflicting results. These studies apply different methods of estimating the (marginal) cost of debt finance and the level of CSR. ${ }^{5}$

Contrary to their hypothesis, Sharfman and Fernando (2008) find a positive relationship between CSR (operationalized as environmental risk management) and the marginal cost of borrowing for 267 large publicly traded US companies (where

\footnotetext{
5 Ye and Zhang (2011), Jung et al. (2018), and La Rosa et al. (2018) use the total cost of debt directly derived from company disclosures equal to the ratio of a firm's interest expense to interest-bearing debt outstanding. However, this estimation does not precisely approximate marginal interest rates.
} 
cost of debt is estimated from a proprietary Bloomberg Financial dataset). Also for the US-setting, based on a larger sample of 1534 firms from 1991 to 2006, Goss and Roberts (2011) generally support these counter-intuitive results, showing that lenders are indifferent to CSR investments by high quality borrowers. In contrast, Chava (2014) shows that banks charge firms with environmental concerns a higher loan interest rate and Oikonomou et al. (2014) find that good social performance of is rewarded by lower U.S. corporate bond yield spreads. Data from publicly listed Chinese firms support a U-shaped relationship between CSR and total cost of debt, where CSR is operationalized as a single proxy equal to the ratio corporate charitable donations to sales (Ye and Zhang 2011). Gong et al. (2018) find a negative relationship between Rankins CSR ratings (third party agency) and the cost of Chinese corporate bonds. Kim et al. (2014) and Hoepner et al. (2016) find that, internationally, CSR (or ethical behavior) reduces financing costs based on insights from bank loan agreements.

The first study to examine European corporate bonds finds that an assumed relationship between CSR and credit spreads has to be generally rejected; concluding that credit ratings matter more for bond investors than CSR ratings (Menz 2010). Finally, La Rosa et al. (2018) argue for and empirically show a negative relationship between CSR and total cost of debt based on a large panel of European companies. Their study is most closely related to ours. However, their inferences are merely based on the social dimension of CSR (Thomson Reuters ASSET4 social pillar score) and do not account for the environmental, and governmental performance of companies. Our study complements their findings by taking a wider perspective on CSR while also examining significant moderating impact of firm's financial distress as a relevant context variable.

Previous studies provide apparently inconclusive evidence, possibly due to the heterogeneous operationalization CSR, different methods of estimating the cost of debt, country-specific differences, and the shifting perception and valuation of CSR over time.

\section{Theory and hypotheses}

\subsection{CSR-performance and the cost of debt}

A positive association between CSR and COD can be derived from stakeholderagent theory (Hill and Jones 1992), which extends the principal-agent paradigm of financial economics (Jensen and Meckling 1976) by integrating a broader stakeholder focus (Freeman 1984). The underlying assumption is that CSR activities lower information asymmetries, reduce suspicion of opportunistic management behavior and mitigate conflicts of interests between relevant stakeholder groups. Similarly, stakeholder engagement can lower capital costs through superior relationships with banks and bondholders and credibly convey a greater long-term orientation of company. CSR engagements can generate moral or reputational capital of stakeholders whose assessment of possible negative business developments or managerial misconduct in the future is effectively mitigated (Fombrun et al. 2000; 
Godfrey 2005). To the extent that stakeholder expectations are fulfilled through sustainability management, better CSR ratings can lead to better financial performance (Jones 1995; Waddock and Graves 1997). Proactive corporate responsibility regarding its interactions with society and its preservation of natural resources can attract high-quality employees, improve the loyalty of suppliers and customers and prevent government sanctions.

The financial outcome of CSR may also depend on firm-specific resources and capabilities, which are important for understanding the sources of sustained competitive advantage of firms (Barney et al. 2011; Torgusa et al. 2012). This resourcebased-theory (RBT) of the firm argues that firm performance depends on a bundle of unique and heterogeneous firm-specific resources, both tangible and intangible, which need to be integrated and deployed most effectively through firms' capabilities (Wernerfelt 1984; Barney 1991; Grant 1991). Engagement in CSR activities can improve corporate reputation (Jenkins 2009), which is a valuable, inimitable and non-substitutable intangible resource. Likewise, CSR activities may foster advantageous capabilities, such as a shared corporate vision and employee involvement (Hart 1995). Based on RBT, McWilliams and Siegel (2001) constructed a formal model of "profit-maximizing" CSR and show managers can derive the ideal level of CSR by conducting cost-benefit analysis. In that regard, the input and output of valuable resources associated with CSR activities need be evaluated in the light of the firms' organizational capabilities.

The concept of an ideal level of CSR is also a central theme of risk-management perspective on CSR. Godfrey (2005) shows that the optimal level of CSR depends on the reduction of risks by means of the economics of insurance (Mayers and Smith 1982; Cummins et al. 1992). Accordingly a company's shareholder value function $\left(W_{s}\right)$ can be described with certainty as $W_{s}=A+L-p$, where A are risk-free assets, $\mathrm{L}$ are assets at pure risk of loss and $\mathrm{p}$ is an insurance premium that covers the loss of L, which takes effect with a probability a. The risk management perspective proposes that the level of insurance coverage increases with greater CSR expenditures due to the generation of moral capital or goodwill. This implies that the optimal level of CSR for shareholders $\left(p_{s} *\right.$ ) maximizes $W_{s}$ when the expected shareholder wealth: $E\left(W_{s}\right)=A+(1-a) L=A+L-p_{s} *$. These conceptual considerations are in line with several studies that provide instance for a non-linear relationship between CSR and shareholder value (Pava and Krausz 1996; Wang et al. 2008).

However, interests of shareholders often diverge from those of creditors: "Some corporate decisions increase the wealth of stockholders while reducing the wealth of bondholders and, in cases where the wealth transfers are large enough, stock prices can rise from decisions that reduce the value of the firm" (Jensen and Smith 1985, p. 22). Generally, creditors are not interested in maximizing shareholder wealth, but in minimizing default risk (Merton 1974). Therefore, they have a greater interest that material environmental, social, and governmental matters are transparently disclosed and mitigated through CSR activities. They can also require the inclusion of ESG-specific covenants in transaction documents such that the issuing company has to comply with certain sustainability policies or practices (O'Sullivan and O'Dwyer 2015; PRI 2018). Arguably, creditors can exercise more direct monitoring over unsustainable management practices than shareholders, who, for example, 
face principal-principal conflicts (i.e. conflicts of interest between SR investors and conventional investors). As quasi-insiders, large financial institutions have not only access to additional company disclosures but can also leverage their direct influence to require greater corporate sustainability. In any case, it follows that creditors are interested in CSR performance and expenditures beyond the optimal level for shareholders as long as there is a marginal reduction in default risk. At the same time, capital invested in CSR can prevent or reduce corporate activities that are detrimental to fixed-income investors, such as increasing dividend payouts, investments in high-risk projects (asset substitution), or underinvestment in low-risk projects that accrue to creditors (Jensen and Smith 1985). Therefore, the cost of insurance is not the same for creditors and shareholders and the optimal level of CSR for creditors $\left(p_{c}\right.$ *) is greater than for shareholders, such that: $\mathrm{E}\left(W_{c}\right)=A+(1-a) L<A+L-p_{c} *$. In fact, to the extent that that greater CSR expenditures can truly mitigate the risk of loss (a), we can expect a linear relationship between CSR and creditor value; and when the value of a bond increases its yield to maturity decreases.

H1a: There is a negative association between CSR and COD.

Assuming that the risk of loss (a) is greater for riskier companies in relative financial distress, the value of insurance-like protection increases. These companies possess more risky assets that can decrease in value due to extraordinary depreciation or impairments, which can decrease their ability to pay interest to creditors. Thus, we hypothesize that the association between CSR and COD is moderated by the probability (risk) that a company defaults on its obligation to pay interest to creditors.

H1b: The negative association between CSR and COD is stronger for companies in financial distress.

\subsection{CSRA and the cost of debt}

Managers possess substantial leeway regarding the extent and usefulness of CSR disclosure, which they can exploit to present their CSR activities in a more favorable way (Magness 2006). As documented by KPMG (2017), there is a global and steady trend towards third-party CSR assurance (CSRA); with $45 \%$ of the top 100 companies from 49 countries (N100) surveyed in 2017 investing in this type of assurance. Despite the increasing relevance of and reliance on independent CSRA (Simnett et al. 2009; Maroun 2018), there is still relatively few research to inform managers and other stakeholders about its merits and constraints (Cohen and Simnett 2015). Yet, Casey and Grenier (2015) show that it is beneficial for U.S. firms to receive CSRA, due to lower cost of equity capital along with lower analyst forecast errors and disparity. Assumedly important stakeholders are more likely to regard CSR activities as credible and trust that CSR reports are not merely self-promotional documents strategically used for 'green-washing' and 'impression-management' (Sethi et al. 2017; Maroun 2018). Thus, CSRA can effectively reduce information asymmetries and contribute to satisfying the information needs of relevant 
stakeholders (O'Dwyer and Owen 2007). From an agency perspective, external CSRA is a monitoring tool, which can increase the value of the firm (Jensen and Meckling 1976). Similarly, signalling theory (Spence 1973; Morris 1987) suggests that companies incur the costs of assurance in order to indicate to the addressees of CSR information that the company is committed to high-quality reporting (Simnett et al. 2009). This can bolster the stakeholders' confidence in CSR reporting and effectively reduce existing information asymmetries. We add to the research stream on output factors of CSRA. While previous studies provide generally mixed results regarding CSRA and stakeholder reactions (Velte and Stawinoga 2017), nothing is known about the association between CSRA and COD. Because CSRA decreases conflicts of interests between stakeholders and increases CSR reputation (Simnett et al. 2009), we expect a negative association between CSRA and COD. We expect this to be the case to the degree that creditors do not regard CSRA expenditures as a waste of scarce resources that would not contribute to a reduction in default risk of companies.

H2: There is a negative association between CSRA and COD.

\subsection{Board characteristics and the cost of debt}

There is a rich amount of research that investigates the relevance of board characteristics for the monitoring of management behavior (e.g. Desender et al. 2013; Goranova et al. 2017); and for the financial performance and investment strategies of companies (Kor 2006). In particular, lending agreements typically require the involvement of the board of directors who supply audited financial statements to the firm's creditors (Dichev and Skinner 2002). However, there is a relative lack of research regarding the examination of associations with COD in this context (Anderson et al. 2004; Chuluun et al. 2014). Hence, instead of examining only an aggregated governance score, we further examine specific board characteristics.

The board of directors plays a central role in determining a company's CSR activities (Godos-Díez et al. 2018). From a stakeholder perspective, the board is responsible for balancing the interests of the company's different stakeholders (Ingley and van der Walt 2004). A greater percentage of board members with board specific skills (operationalized as either an industry specific background or strong financial background) may affect firm performance and strategic decisions, such as financing choices and investments in high or low risk projects (Defond et al. 2005; Güner et al. 2008; Dass et al. 2014; Minton et al. 2014; Wang et al. 2015; Oehmichen et al. 2017). In particular, industry experts with strong financial skills may be able to spot industry trends at the onset, and thus be willing to invest more aggressively in new profitable, but risky, business ventures (Oehmichen et al. 2017).

Another relevant characteristic in previous research is board independence. The predominant view is that board independence mitigates agency conflicts (Fernández-Gago et al. 2016; Shaukat and Trojanowski 2018) and reduces earnings managements (Prencipe and Bar-Yosef 2011), such that a negative association with COD appears most likely. However, previous results are not entirely conclusive and board 
independence may increase the agency conflicts between shareholders and bondholders (Bradley and Chen 2015).

The corporate governance literature on board size provides competing arguments regarding monitoring effectiveness. On the one hand, larger boards are more likely to engage with a wider range of stakeholders and therefore could lead to better CSR. Similarly, prior research finds a positive association between board size and firms' financial performance (e.g. Belkhir 2009). We would expect this to reduce the COD. On the other hand, larger boards may experience more difficulties in reaching agreements and relevant issues may not be addressed in a timely manner (Eisenberg et al. 1998), which could be detrimental to creditors and other stakeholders.

Further research focusses on the link between board gender diversity and financial and CSR, with generally mixed results (see: Velte 2017 for a comprehensive review). These studies have a strong focus on shareholder value (e.g. Campbell and Mínguez-Vera 2008; Chapple and Humphrey 2014; Abdullah et al. 2016). To the extent that board gender diversity is associated with a lower propensity to invest in high-risk project (Jianakoplos and Bernasek 1998), we expect a negative association with COD.

Finally, we also include the average board tenure during the reporting year in our analysis. There is some evidence for an association between board tenure and firm performance (Huang and Hilary 2018) and corporate yield spreads (Anderson et al. 2004). Greater board tenure potentially leads to a greater alignment with a manager's high-risk taking propensity and could thus be lead to greater COD. On the other hand, board tenure could be negatively associated with COD due to a more conservative approach towards credit financing. Based on a review of previous research and the evaluation of existing theoretical arguments, we formulate the following hypotheses regarding different board characteristics.

H3a: Board specific skills are positively associated with COD.

H3b: Board independence is negatively associated with COD.

H3c: Board size is negatively associated with COD.

H3d: Board gender diversity is negatively associated with COD.

H3e: Board tenure is negatively associated with COD.

\section{Research design}

\subsection{Sample selection}

The sample selection and composition are presented in Table 1. Sample selection begins with all European companies with available ESG data on Thompson Reuters Datastream/ASSET4 database for the years of 2014-2017. This database covers well-established equity indices of publicly listed companies in Europe, and not just a specific sample of firms that engage in CSR. Due to time-lagged measurement for CSR, sample size is reduced by 1190 firm-year observation. Furthermore, we exclude 293 financial services firms, which reduces the sample by 879 firm-year observations. After excluding 574 firm-year observations due to missing values for 
Table 1 Sample selection and composition

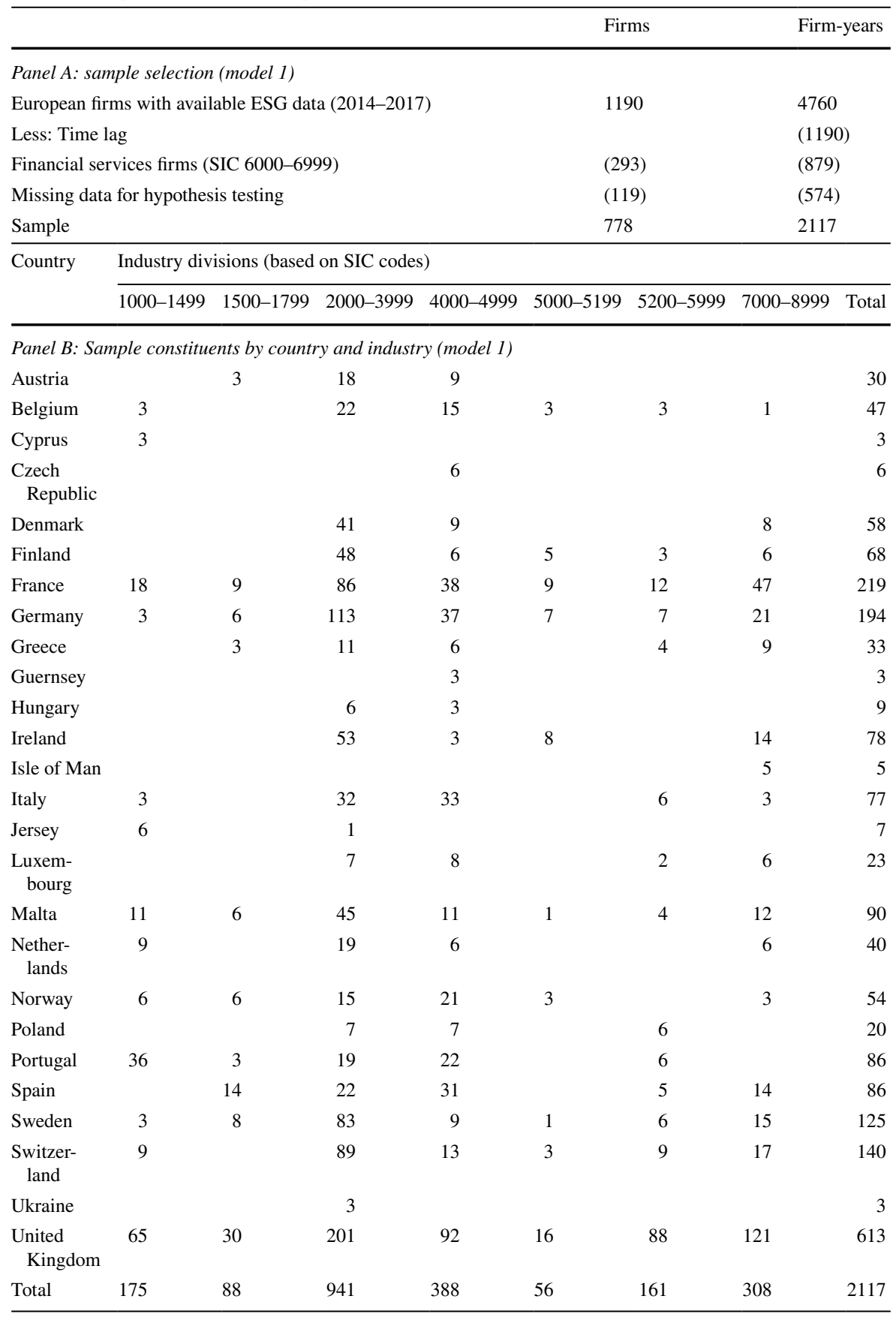

Panel A describes our samples selection process. Panel B depicts the countries included in our dataset. All results are robust to excluding countries with less than 10 firm-year observations 
hypotheses testing, the sample comprises of 2117 firm-year observations of 778 European companies. This sample represents our baseline model for testing H1. Missing values in the database are not due to specific firm characteristics. Because ASSET4's company coverage evolved over time starting with the largest European companies and starting with the most prominent European stock indexes, our sample covers the most relevant European companies in terms of market capitalization. For illustration purposes, we note that our sample covers most (71\%) of the companies listed in the FTSE Eurotop 100 Index. This index represents the performance of the 100 most highly capitalized blue chip companies based in the European countries that form part of the European Monetary Union. Of the 29 companies that are not part of our sample, but are included in the FTSE Eurotop 100 Index, 20 companies operate in the financial services sector and 9 companies have missing values for hypotheses testing. In total, we regard the final sample as representative for large publicly listed European companies.

\subsection{Dependent variables}

To achieve greater robustness of our model design and validity of the findings, we use three dependent variables: COD, COLD and RATING. Our main dependent variable is COD, which is the average marginal cost to the company of issuing new debt. It is calculated as the weighted after-tax cost of short-term and weighted aftertax cost of long-term debt based on the 1-year and 10-year points of the appropriate credit curve for the focal company. In additional analysis, we also use COLD, which is the marginal cost of long-term debt. We use both COD and COLD as dependent variables because of (1) a nonmonotonic relation between debt maturity and bond ratings (Stohs and Mauer 1996) and because (2) high CSR firms may reduce their debt maturity to signal superior quality and manage problems of overinvestment in CSR (Benlemlih 2017). A shift towards short-term debt financing with increasing CSR would lead to lower average cost of debt. Thus, we are testing for a potentially different impact of CSR on COD than on COLD. Because both of those variables are not directly observable from company disclosures, we rely on proprietary data provided by the data analytics firm 'StarmineAnalytics' for these metrics. The determination of the appropriate credit curve for a company considers various risk factors, including company-specific information, credit ratings, and the current economic environment. In addition, the proprietary StarMine Combined Credit Risk model is utilized. This model extends the structural default prediction framework by Robert Merton (1974) by a wide array of accounting ratios that are predictive of credit risk. These ratios are derived from both financial disclosures and forwardlooking analyst estimates. The combined risk model assesses credit risk along the five dimensions profitability, leverage, interest and debt coverage, liquidity, growth 
and stability; and also includes sophisticated text mining algorithms from a wide array of regulatory filings to identify language that is predictive of credit risk. ${ }^{6}$

Lastly, in additional analysis, for further robustness of our findings, we also use Fitch credit ratings (RATING) as a third dependent variable. However, it should be noted that their ratings are not available for all companies and are time-invariant for the vast majority of companies in our sample.

\subsection{Explanatory variables}

There is no single way to measure CSR. While some studies rely on aggregated ESG scores from databases, others construct a CSR score based on a set of selected variables, or proxy CSR by the means of a single variable. To test H1a and H1b this study primarily uses the equally weighted ESG score by Thomson Reuters/ASSET4, which is commonly used in related studies (e.g. Cheng et al. 2014). Moreover, we examine the environmental, social and governmental pillar scores separately to get a better understanding of the latent concept of CSR. As a proxy for CSR leadership outside the ASSET4 universe, we also collect data on listings in the regional Dow Jones Sustainability Index (DJSI Europe) for each company-year combination in our panel analysis. This approach follows an emergent research stream on the relevance and meaning of sustainability index listings as part of the broader SRI literature (López et al. 2007; Consolandi et al. 2009; Gerwanski et al. 2019). For testing H1b, we use the interest coverage ratio (INT_COV) as a proxy for financial distress. The variable measures a company's ability to satisfy its interest obligations. It is calculated by dividing a company's earnings before interest and taxes during a given period by the company's interest payments. To test $\mathrm{H} 2$ we include a dummy variable that takes a value of one if the company has an external auditor of its CSR report, and zero otherwise. Finally, regarding H3 we include several variables to measure board characteristics. Specifically, we examine the board specific skills, board independence, board size, board gender diversity, and board experience. All variables are defined in Table 2.

\subsection{Control variables}

In line with previous research, this study controls for a wide array of risk factors that are assumed to have an impact on COD. SIZE is the natural logarithm of company assets. BETA represents the company's stock price sensitivity to market volatility. LEVERAGE is the ratio of total liabilities to total assets. TANGIBILITY is the ratio of total property, plant, and equipment to total assets. To further control for firm fundamentals, we include Piotroski's (2000) F-score, which is constructed from nine fundamental signals and is thus a more comprehensive measure for a firm's financial

\footnotetext{
${ }^{6}$ Further information on Starmine Quantitative Analytics is available here: https://www.refinitiv.com/ content/dam/marketing/en_us/documents/brochures/starmine-quantitative-analytics-brochure.pdf (Accessed: 24 February 2020).
} 


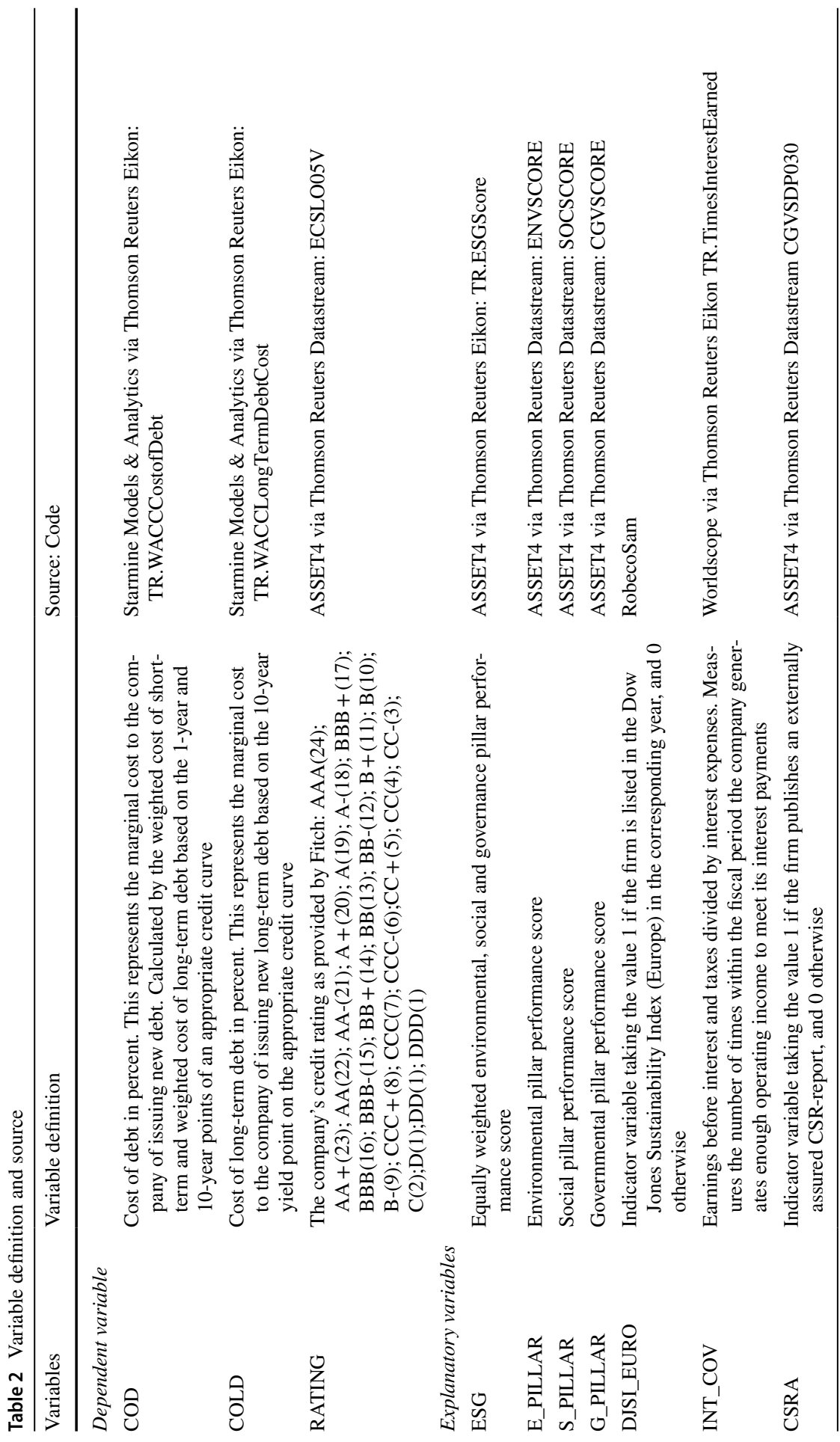




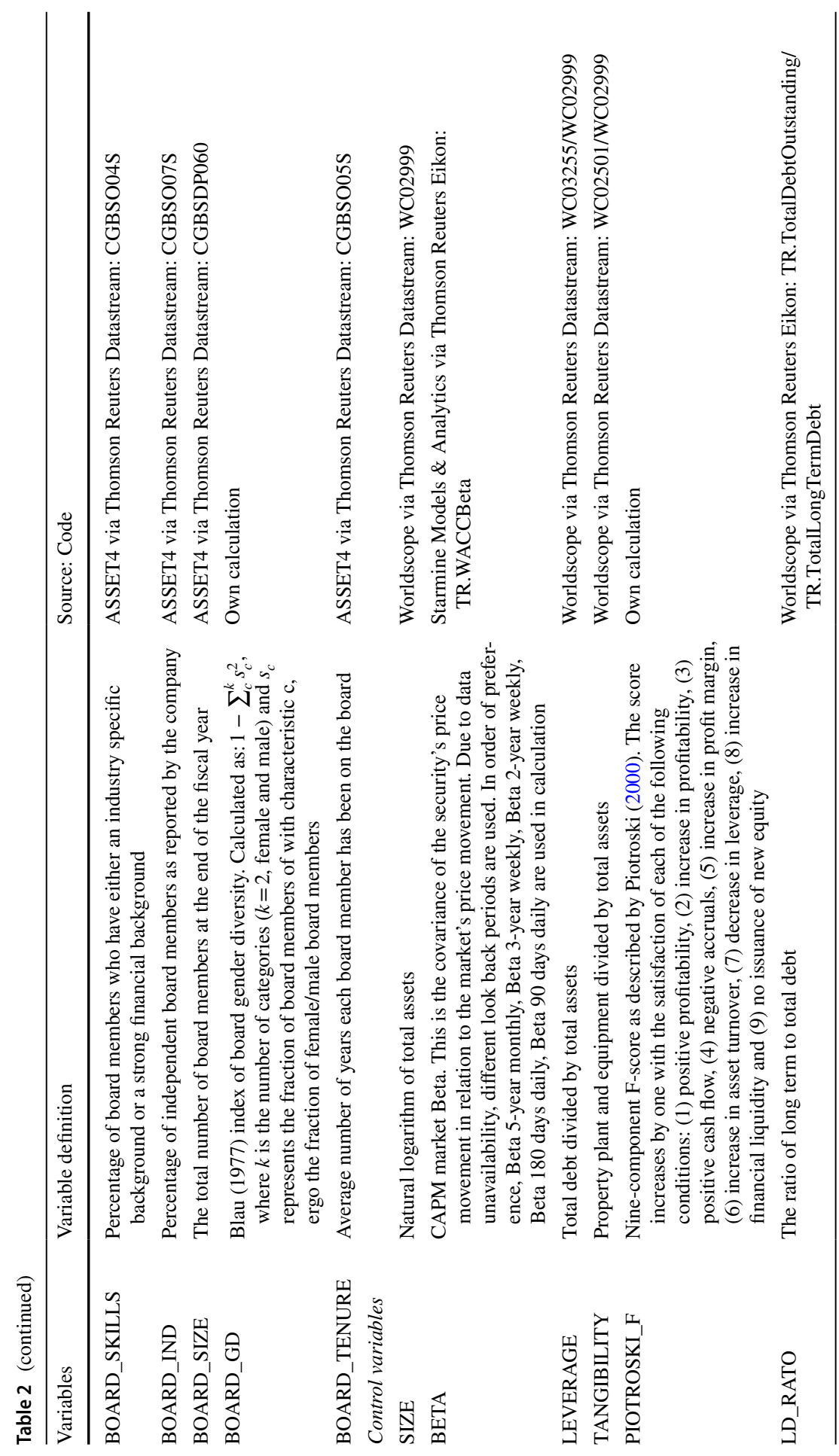




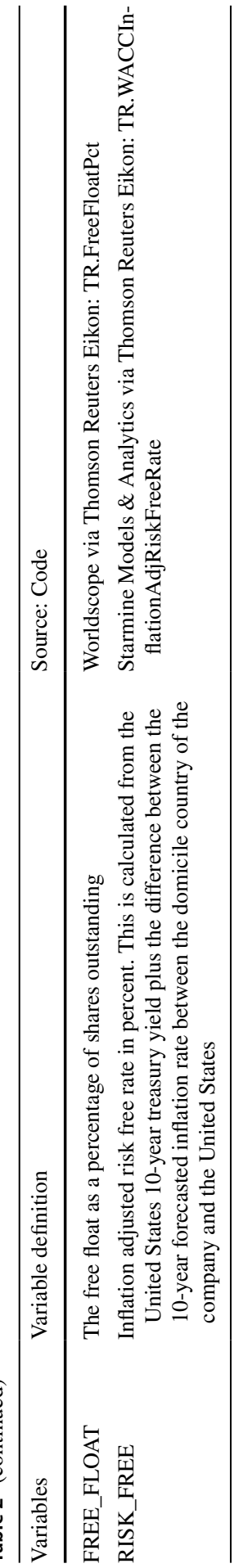


health than Tobin's Q or return on assets (Chung et al. 2015). LD_RATIO controls for the ratio of long term to short term debt. FREEFLOAT represents the portion of shares of a corporation that are in the hands of public investors as opposed to locked-in stock held by institutional investors. Because these investors have high significance in credit markets, they could be able to charge higher interest rates (Goss and Roberts 2011; Menz 2010). Finally, we are including the inflation adjusted riskfree interest rate (RISK_FREE) to model time and country specific risk determinants. All results are qualitatively the same when we are instead including year fixed and country fixed effects. We are including industry fixed effects to control for unobserved heterogeneity inherent to firms operating in different industries.

\subsection{Statistical methods}

The empirical analysis is based on a large panel of European companies. In line with earlier research in this field (e.g. Ye and Zhang 2011; La Rosa et al. 2018) we performed pooled multiple regression analysis (OLS) with heteroscedasticity robust standard errors. ${ }^{7}$ To address the panel data structure of our research design, standard errors are clustered at the firm level. We use one-year time lagged ESG scores "to minimize problems that might exist due to potential endogeneity" (Stellner et al. 2015, p. 17). From a theoretic perspective, the positive market reactions due to CSR activities are unlikely to materialize immediately. In order to test hypothesis $1 \mathrm{~b}$, we include the interaction between ESG and INT_COV. We operationalize the interest coverage ratio as a proxy for financial distress (e.g. Dothan 2006), where a lower value represents a greater probability of default on interest payments. To address the multi-level structure of our data, where occasions are nested in firms and firms are nested in countries, we further specify an appropriate three-level variance component model based on maximum likelihood estimation. This allows us to assess how much of the variation of our data is explained at each hierarchical level of our data.

To address concerns of endogeneity, which can be relevant in this stream of research, we follow the approach applied by Cheng et al. (2014) who investigated the impact of CSR on the access to finance. Accordingly, we are implementing instrumental variables and simultaneous equations specifications. While this produces consistent results, this approach leads to an inevitable loss of efficiency as compared to pooled OLS estimation. We calculate the country-sector and country-year average (excluding the focal firm) for instruments for our primary CSR measure (ESG). For the instrumental variables approach, we implement a generalized method of moment (GMM) estimator. In the presence of heteroscedasticity or clustered errors, this estimator remains consistent and standard errors are valid for inferences and diagnostic testing. Specifically, we are using the instrumental variable twostep feasible efficient

\footnotetext{
7 We refrain from specifying firm-level fixed effects (least squares dummy variable model) for two main reasons. First, we are primarily interested in differences across firms (while controlling for relevant confounding factors as derived from theory and literature). Second, our dependent variables (COD, COLD, and RATING) as well as our main variables of interest (ESG, CSRA, the pillar scores, and the board characteristics) are relatively time-invariant over our three-year period of analysis.
} 
Table 3 Summary statistics

\begin{tabular}{lrrrrr}
\hline Variables & \multicolumn{1}{c}{$\mathrm{N}$} & \multicolumn{1}{c}{ Mean } & \multicolumn{1}{l}{ SD } & \multicolumn{1}{l}{ Min } & \multicolumn{1}{l}{ Max } \\
\hline COD & 2117 & 2.327 & 1.896 & -0.343 & 18.861 \\
COLD & 2117 & 3.577 & 2.478 & 0.000 & 23.904 \\
RATING & 505 & 15.893 & 3.019 & 1.000 & 23.000 \\
ESG & 2117 & 59.546 & 15.820 & 9.346 & 94.464 \\
E_PILLAR & 2117 & 63.520 & 20.119 & 5.147 & 99.226 \\
S_PILLAR & 2117 & 62.733 & 19.929 & 4.331 & 99.037 \\
G_PILLAR & 2117 & 51.407 & 20.527 & 2.826 & 95.053 \\
DJSI_EURO & 2117 & 0.075 & 0.263 & 0.000 & 1.000 \\
INT_COV & 2117 & 20.201 & 31.328 & -0.293 & 132.245 \\
CSRA & 2117 & 0.532 & 0.499 & 0.000 & 1.000 \\
BOARD_SKILLS & 2086 & 41.938 & 21.592 & 0.000 & 100.000 \\
BOARD_IND & 2117 & 46.584 & 26.196 & 0.000 & 100.000 \\
BOARD_SIZE & 2117 & 10.537 & 3.651 & 3.000 & 27.000 \\
BOARD_GD & 2117 & 0.318 & 0.142 & 0.000 & 0.500 \\
BOARD_TENURE & 1777 & 6.220 & 2.572 & 0.000 & 20.813 \\
SIZE & 2117 & 22.385 & 1.492 & 17.059 & 26.769 \\
BETA & 2117 & 0.945 & 0.450 & -0.264 & 3.840 \\
LEVERAGE & 2117 & 0.263 & 0.179 & 0.000 & 1.674 \\
TANGIBILITY & 2117 & 0.281 & 0.222 & 0.000 & 0.912 \\
PIOTROSKI_F & 2117 & 4.571 & 1.090 & 0.000 & 7.000 \\
LD_RATO & 2117 & 0.770 & 0.247 & 0.000 & 1.001 \\
FREE_FLOAT & 2117 & 74.096 & 25.370 & 0.524 & 100.000 \\
RISK_FREE & 2117 & 2.270 & 0.557 & 1.364 & 5.559 \\
\hline & & & & &
\end{tabular}

GMM estimator with the corresponding variance-covariance matrix as described in Baum et al. (2007) and as applied in related studies, such as Cheng et al. (2014). For our system of equations we are constructing similar instruments for COD (i.e. the average COD for each country-sector pair and country-year pair) and use three-stage least squares (3SLS) estimation to produce consistent estimates derived from our instruments in the first stage and implement them in generalized least squares (GLS) regressions for our two simultaneous equations (Wooldridge 2007). We are dropping country-sector and country-year pair instruments with less than 10 observations. This has no meaningful impact on the result described below.

\section{Results}

\subsection{Descriptive statistics}

Table 3 provides summary statistics for the study variables, and Table 4 presents the correlation matrix among the variables. On average, the COD (COLD) is 2.327 percent (3.577 percent), with a substantial standard deviation of 1.896 (2.478). The 


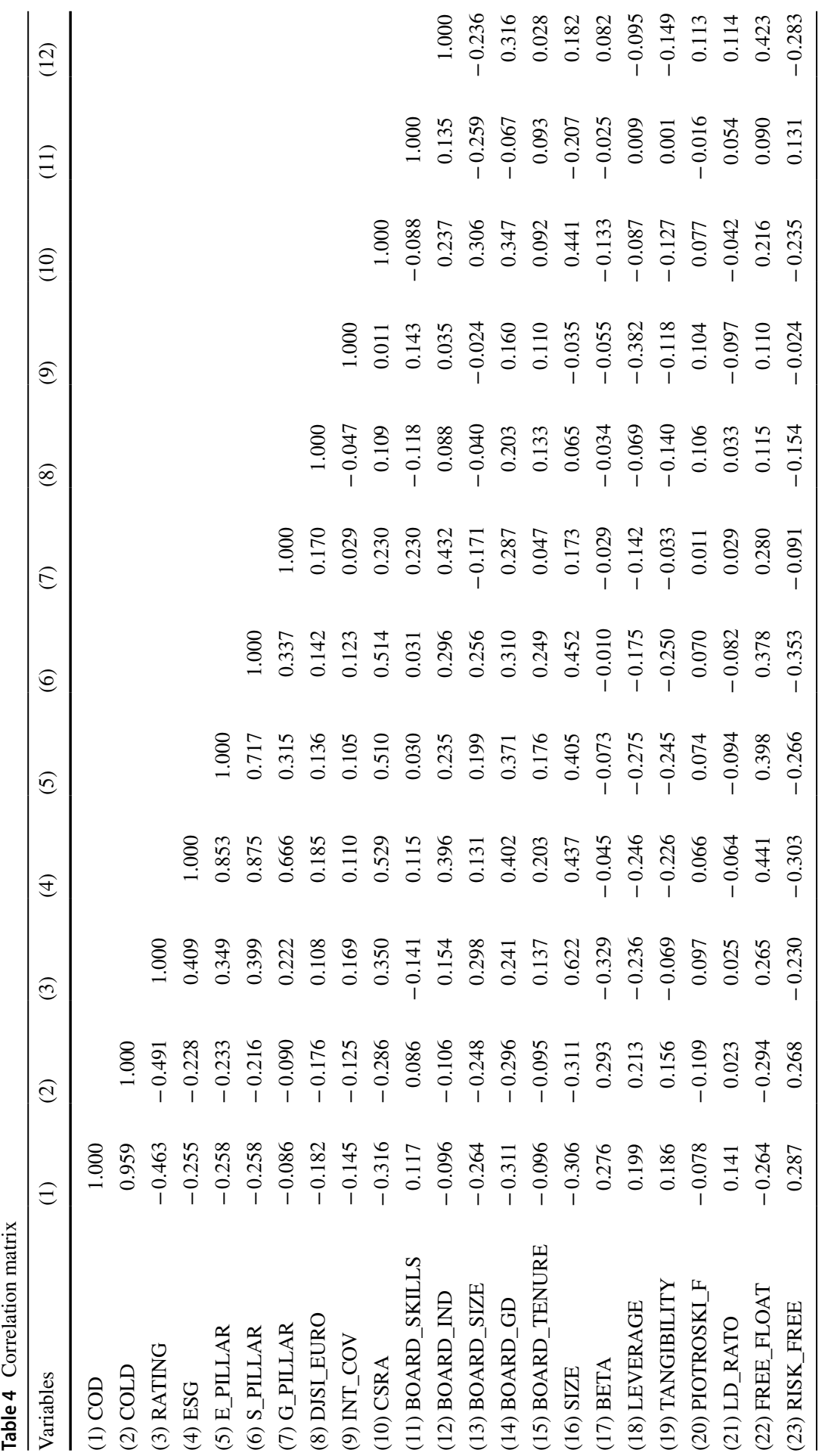




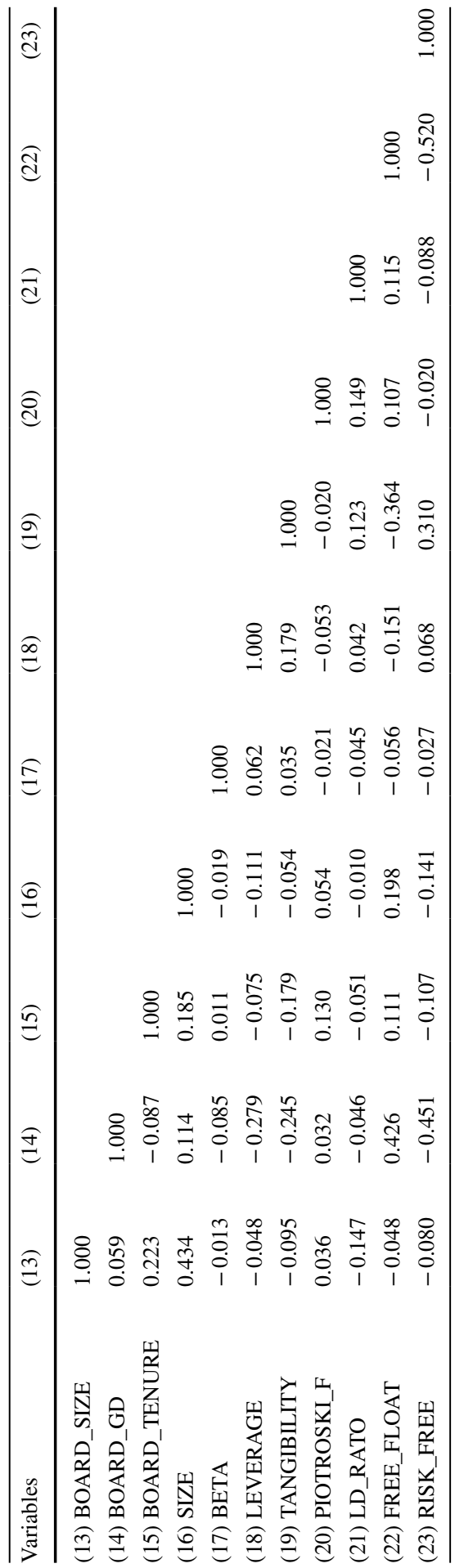




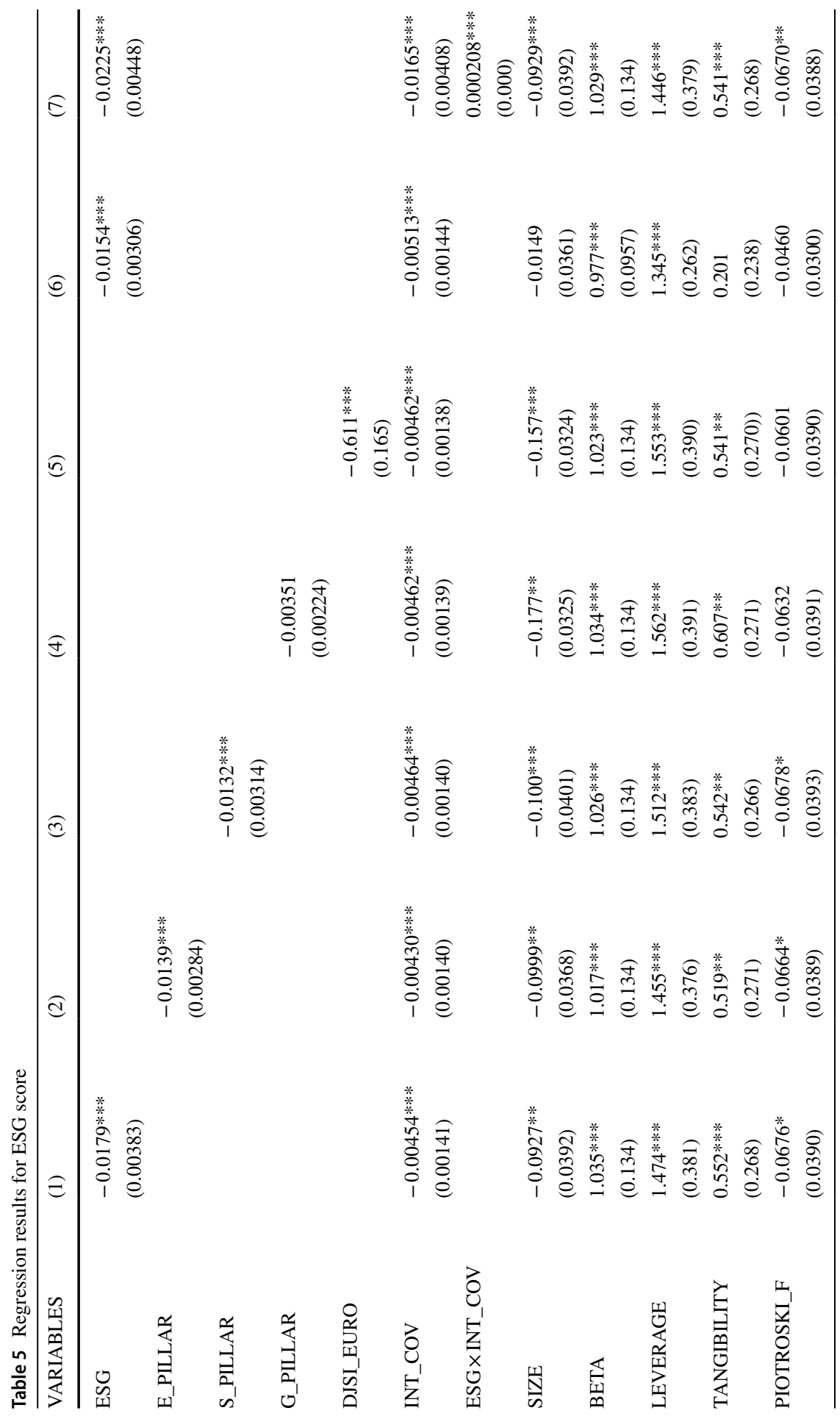




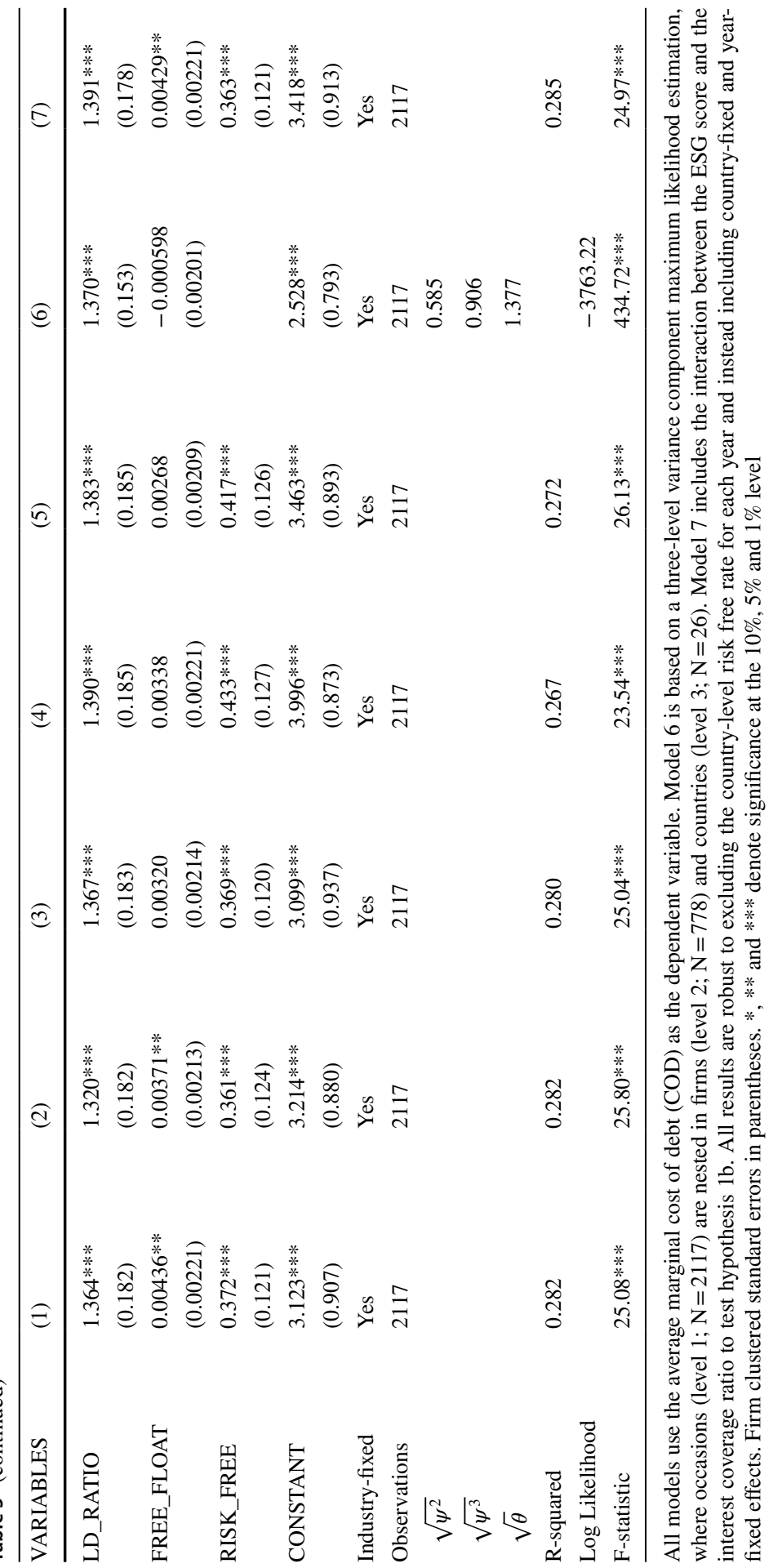


average ESG z-score is $59.546(\mathrm{SD}=15.8320)$ and is negatively correlated to COD $(-0.255 ; p$ value $=0.000)$ and $\operatorname{COLD}(-0.228 ; p$ value $=0.000)$. The mean variance inflation factor (VIF) of our main model (Table 5, model 1) is 1.81 . The values are similar for all other models with, as is expected, slightly higher values when interactions are included. Across all models, there is no concern with regard to multicollinearity $(\mathrm{VIF}<10)$.

\subsection{Baseline regression results}

Table 5 presents our results for testing $\mathrm{H} 1 \mathrm{a}$ and $\mathrm{H} 1 \mathrm{~b}$ based on various model specifications. The coefficient estimates of model 1 to 7 are based on a pooled OLS regression with firm clustered standard errors and with COD as the dependent variable. In line with our expectations, we find a negative association between CSR and credit financing costs. Every unit increase of our primary measure for CSR (ESG) decreases COD by 0.0179 ( $p$ value $=0.000$ ). Those finding are economically significant and suggest that greater CSR has a meaningful impact of a company's debt financing costs. The estimated coefficient of model 1 implies that a one-standard deviation increase in ESG leads firms' COD to decrease, on average, by 33.9 basis points. The differentiation between the three pillar scores (Table 5, model 2, 3, 4) suggests that the firms' environmental and social performance are more relevant than the governmental performance for credit decisions. Only the governmental pillar score lacks statistical significance and the economic relevance is distinctively lower. Further analysis (Table 5, model 5) reveals that DJSI (Europe) listed firms benefit from lower COD by 61.1 basis points ( $p$ value $=0.000$ ).

The coefficients of Table 5 model 6 are derived from a three-level variance component maximum likelihood estimator, where occasions (level 1; $\mathrm{N}=2117$ ) are nested in firms (level 2; $\mathrm{N}=778$ ) and countries (level 3; $\mathrm{N}=26$ ). The estimated residual standard deviation of COD between countries $\left(\sqrt{\psi^{2}}\right)$ and between firms $\left(\sqrt{\psi^{3}}\right)$ is 0.585 and 0.906 , respectively. The remaining residual standard deviation $(\sqrt{\theta})$ is estimated as 1.377 . We calculate the variance partition coefficients (VPC) to measure the relative magnitude of the variance components caused by the corresponding random effects (Anderson et al. 2010). Accordingly, 26.5\% $\left(\mathrm{VPC}_{\text {(country) }}=0.265\right)$ of the total variance lies between countries (i.e. betweencountry differences), 32.9\% $\left(\mathrm{VPC}_{(\text {firm })}=0.329\right)$ lies between firms (i.e. between-firm differences), and $40.8 \%\left(\mathrm{VPC}_{\text {(occasion) }}=0.408\right)$ lies within firms between occasions (i.e. within-firm differences). These values indicate that a multi-level specification is appropriate (Hox 2010) and that allowing for a random intercept across firms and countries is superior as compared to a one-level linear regression model (likelihood ratio $(\mathrm{LR})$ test is significant, $p$ value $=0.000)$. While the coefficient of ESG for this model specification is slightly higher $(-0.0154)$, this still supports the statistical and economic relevance of the negative association between CSR and the COD ( $p$ value $=0.000$ )

Model 7 of Table 5 includes the interaction ESG $\times$ INT_COV to test the moderating influence of financial distress on the association between CSR and COD, as outlined by $\mathrm{H} 1 \mathrm{~b}$. The results suggest that the negative association is significantly 


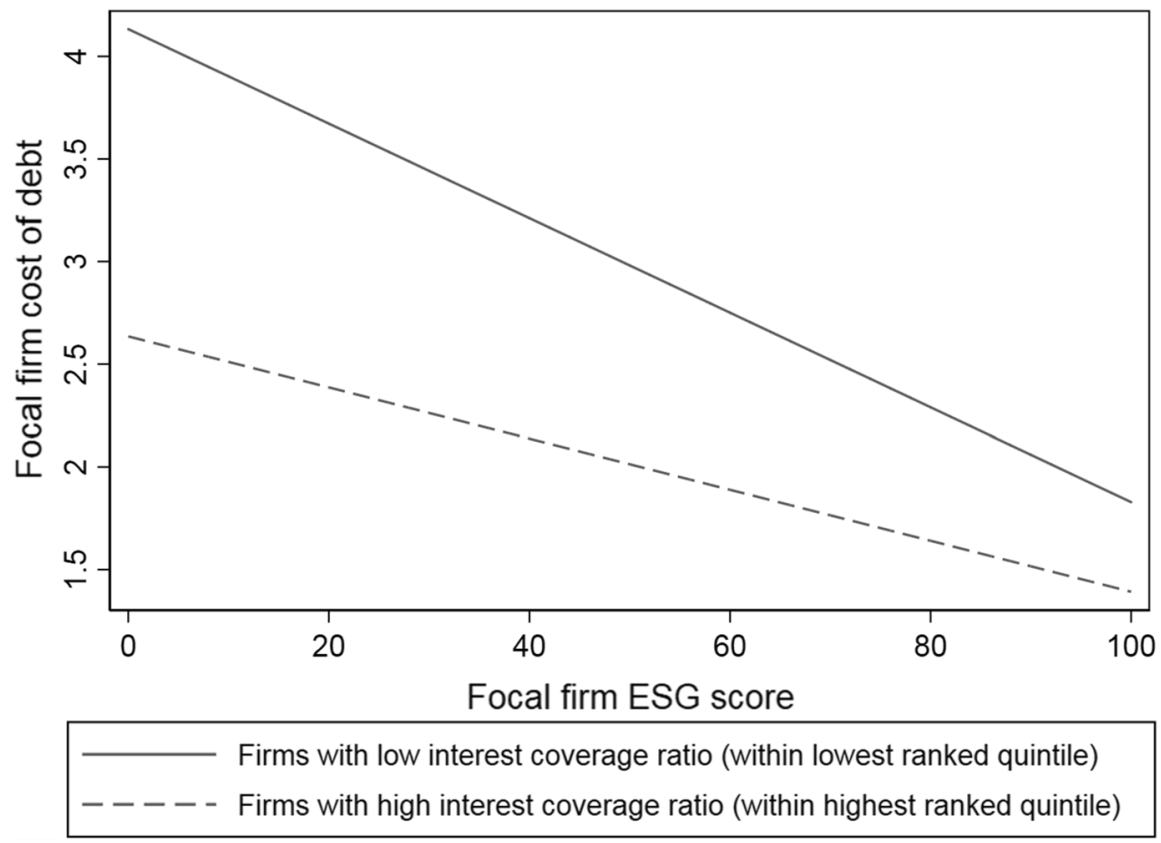

Fig. 1 Effect of interaction between ESG score and the interest coverage ratio on a firm's subsequent COD

lower $(p$ value $=0.000$ ) when a company is in good financial health (low probability of default), as approximated by the interest coverage ratio. This moderating property is illustrated by Fig. 1, showing the effect of interaction between ESG and the INT_ COV on a firm's subsequent COD Supporting H1b, this implies that the insurancelike property of CSR is more relevant for firms that are struggling financially.

Model 1 of Table 6 presents the results for H2. Ceteris paribus, companies who invest in CSRA have lower COD of 49.4 basis points, which is both statistically and economically significant $(p$ value $=0.000$ ). This suggests that creditors find external assurance of CSR-reports important to evaluate the credibility of a company's CSR activities and adjust their credit risk analysis accordingly.

Model 2 of Table 6 presents the results for H3. The results indicate that board characteristics can have a significant impact of COD. In particular, we find that board independence ( $p$ value $=0.023)$, board size $(p$ value $=0.000)$ and board gender diversity ( $p$ value $=0.000$ ) seem to reduce the interest requirements of creditors: a one-standard deviation increase leads to, on average, a reduction in COD of 12.5, 22.1 , and 26.1 basis points, respectively. These results are consistent with the explanation that those board characteristics are associated with better stakeholder interaction and lower risk-taking. With regard to board specific skills, we find the opposite association (coefficient $=0.0047 ; p$ value $=0.034$ ). This confirms earlier studies who find that such board members are associated with larger bond issues (Güner et al. 2008) and higher risk-taking (Minton et al. 2014). Lastly, we find no statistically significant association between average board tenure and COD. 
Table 6 Regression results for CSRA and board characteristics

\begin{tabular}{|c|c|c|}
\hline VARIABLES & (1) & (2) \\
\hline CSRA & $\begin{array}{l}-0.494 * * * \\
(0.116)\end{array}$ & \\
\hline BOARD_SKILLS & & $\begin{array}{l}0.00472 * * \\
(0.00222)\end{array}$ \\
\hline BOARD_IND & & $\begin{array}{l}-0.00478^{* *} \\
(0.00215)\end{array}$ \\
\hline BOARD_SIZE & & $\begin{array}{l}-0.0605^{* * *} \\
(0.0170)\end{array}$ \\
\hline BOARD_GD & & $\begin{array}{l}-1.839 * * * \\
(0.404)\end{array}$ \\
\hline BOARD_TENURE & & $\begin{array}{l}-0.0136 \\
(0.0191)\end{array}$ \\
\hline INT_COV & $\begin{array}{l}-0.00506^{* * *} \\
(0.00138)\end{array}$ & $\begin{array}{l}-0.00348^{* *} \\
(0.00159)\end{array}$ \\
\hline SIZE & $\begin{array}{l}-0.107 * * * \\
(0.0371)\end{array}$ & $\begin{array}{l}-0.0619 \\
(0.0421)\end{array}$ \\
\hline BETA & $\begin{array}{l}1.010^{* * *} \\
(0.134)\end{array}$ & $\begin{array}{l}1.038^{* * *} \\
(0.140)\end{array}$ \\
\hline LEVERAGE & $\begin{array}{l}1.509 * * * \\
(0.380)\end{array}$ & $\begin{array}{l}1.821 \text { *** } \\
(0.478)\end{array}$ \\
\hline TANGIBILITY & $\begin{array}{l}0.594 * * \\
(0.268)\end{array}$ & $\begin{array}{l}0.241 \\
(0.276)\end{array}$ \\
\hline PIOTROSKI_F & $\begin{array}{l}-0.0614 \\
(0.0391)\end{array}$ & $\begin{array}{l}-0.0499 \\
(0.0428)\end{array}$ \\
\hline LD_RATIO & $\begin{array}{l}1.318 * * * \\
(0.185)\end{array}$ & $\begin{array}{l}1.450 \text { *** } \\
(0.188)\end{array}$ \\
\hline FREE_FLOAT & $\begin{array}{l}0.00236 \\
(0.00209)\end{array}$ & $\begin{array}{l}0.00310 \\
(0.00252)\end{array}$ \\
\hline RISK_FREE & $\begin{array}{l}0.388 * * * \\
(0.122)\end{array}$ & $\begin{array}{l}0.284 * * \\
(0.131)\end{array}$ \\
\hline CONSTANT & $\begin{array}{l}2.727 * * * \\
(0.951)\end{array}$ & $\begin{array}{l}2.726 * * * \\
(1.007)\end{array}$ \\
\hline Industry fixed effects & Yes & Yes \\
\hline Observations & 2117 & 1749 \\
\hline R-squared & 0.278 & 0.316 \\
\hline F-statistic & $26.50 * * *$ & $24.63 * * *$ \\
\hline
\end{tabular}

Both models use the average marginal cost of debt (COD) as the dependent variable. Model 1 includes CSRA as the explanatory variable to test hypothesis 2 . Model 2 includes several board composition variables to test hypothesis 3 . All results are robust to excluding the country-level risk free rate for each year and instead including country-fixed and year-fixed effects. Firm clustered standard errors in parentheses. *, ** and $* * *$ denote significance at the $10 \%, 5 \%$ and $1 \%$ level 


\subsection{Additional analysis}

In order to test the robustness of your baseline regression results, we conduct a variety of additional analysis, which (for the sake of brevity) remain untabulated. Firstly, we adjust our baseline results by using different dependent and explanatory variables. We test if our results are robust to using long-term credit costs (COLD) as the dependent variable. In line with $\mathrm{H} 1$, we find negative association between CSR and the marginal cost of issuing new long-term debt based on the 10-year yield point on the appropriate credit curve $(-0.0211 ; p$ value $=0.000)$. Further support stems from using RATING as the dependent variable, which suggests that greater CSR is associated with better credit ratings (coefficient $=0.0127 ; p$ value $=0.091$ ). However, it should be noted that credit ratings are not available for most companies in our sample. We also find that the moderation analysis yields qualitatively the same results when we approximate a firm's financial health by its leverage ratio or Piotroski F-score, or when we use COLD as the dependent variable. Moreover, we find that the negative association between CSRA and COD is moderated by the company's state of relative financial distress in the same fashion as described in H1b (coefficient $=0.0032 ; p$ value $=0.065$, interaction: CSRA $\times$ INT_COV). Each one-standard deviation increase in the interest coverage ratio decreases the negative impact of CSRA on COD by 10.0 basis points. Regarding board gender diversity, we find that a critical mass of at least 3 females on the board is associated with a decrease in credit costs of, on average, 35.54 basis points $(p$ value $=0.001)$. Our results are also robust to controlling for institutional ownership variables as classified by Ferreira and Matos (2008). Likewise, addressing any remaining concerns of omitted variable bias, our results (Table 5, model 1) remain the same when including firm dummies (coefficient $=-0.0399 ; p$ value $=0.000$; within $r$-squared $=0.0956$ ).

Secondly, as described in Sect. 4.5, we test the robustness of our results using instrumental variables and simultaneous equations model specification to address the concerns of endogeneity (generally) and simultaneity (specifically). Based on postestimation tests - the Kleibergen-Paab rk LM statistic, the Kleibergen-Paab rk Wald F statistic (Kleibergen and Paap 2006), and the Hansen J statistic (Hansen 1982) — we find that the model is always identified, that the instruments are strong and relevant, and that the instruments are uncorrelated to the error term (i.e. exogenous). In the first stage regression, all instruments show statistical significance at the one percent level. The coefficient of ESG remains negative and significant $(-0.0193 ; p$ value $=0.02)$, suggesting that the exogenous component of CSR negatively impacts COD.

Based on the system on simultaneous equations we find no evidence for a possible simultaneity bias. In line with the results of the pooled OLS estimator, the multi-level maximum likelihood estimator, and the GMM estimator based on exogenous instruments, the three-stage least squares estimation method (3SLS) provides further instance for a causal negative relation between CSR and COD (coefficient $=-0.01,996 ; p$ value $=0.01$ ). Moreover, the system of equations indicates that lower COD does not lead to better CSR in terms of statistical significance (coefficient $=-0.6192 ; p$ value $=0.706 ;$ Fair 1970) 


\section{Discussion and conclusion}

This study extends on the risk management perspective on CSR by theoretically and empirically examining how the European credit market values CSR. We find strong and consistent evidence that socially responsible companies are rewarded with lower COD. This linear relationship is consistent with a diverging value function between shareholders and creditors with regard to the optimal level CSR. We further show that the insurance-like property of CSR is moderated by the financial health (default probability) of companies. The reducing impact of CSR on COD is statistically and economically more relevant when companies are in relative financial distress (i.e. have a low interest coverage ratio, high leverage, or low Piotroski F-score). Additional analysis suggests that CSRA reduces information asymmetries between managers and relevant stakeholders by increasing the credibility of CSR disclosures, which reduces COD. Finally, we provide instance that specific board characteristics are significantly related to the required rate of return of fixed-income investors. Because extant studies provide largely mixed results, we believe that the main driver behind these findings is the shifting institutional logic with regard to the assessment of CSR (Ioannou and Serafeim 2015; PRI 2017), which is potentially more advanced in European countries than elsewhere. The upsurge of institutional and private SR investors, ESG-based risk management and reporting frameworks (e.g. Equator Principles, GRI, IIRC), and the recent regulatory focus on sustainable finance and CSR reporting in Europe (European Commission 2018) support this line of reasoning.

Our results are relevant for the ongoing debate about the value relevance of CSR, implying that managers can reduce debt-financing costs by engaging in credible (externally assured) CSR activities. We also point out that these actions do not necessarily increase the value for shareholders, who assess risk differently than creditors. Previous studies show that the shareholder value function with regard to CSR is U-shaped, such that potential agency conflicts between conventional shareholders and creditors with regard to the optimal level of CSR become apparent. We propose the detailed assessment of these conflicts of interests with regard to CSR as a fruitful avenue for future research. Likewise, future studies could examine in how far institutional fixed-income investors utilize ESG-related debt covenants and other monitoring mechanisms to increase CSR activities of companies.

Our results further contribute to the research stream on the value relevance of specific corporate governance characteristics. We provide instance for economically significant implications of the composition of the board of directors for the credit market. The findings are relevant for the "soft-low" regulation of corporate governance practice in Europe by providing valuable insights for policymakers, directors of listed and unlisted companies, and fixed income investors (e.g. private and institutional bondholders and banks; IFC 2015).

Future research may take a closer look at small and medium-sized companies in the context of associations between CSR and credit costs. In particular, companies that are not listed on any major stock exchange are likely more dependent on bank loans and they may not have the necessary capabilities to effectively communicate their CSR engagements to their stakeholders. Qualitative studies could shed more light upon the mechanisms that exist within credit rating agencies and 
banks and explore to what extent specific CSR activities are predominantly considered in the assessment of appropriate credit costs.

Like any empirical study, our findings should be considered in the light of several limitations. While we use a number of different, fine-grained, approached towards operationalizing CSR, this study mainly relies on CSR ratings provided by Thomson Reuters ASSET4. This is common in related research, but we recognize that CSR and the validity of CSR disclosure is not directly observable. Similarly, the importance of specific CSR metrics (the ESG z-score consists of 400 evaluation points per firm) could vary across firms, industries, countries, and investors. While we employ several methods for controlling for such unobserved heterogeneity, explicitly modelling all these effects is unattainable. We also note that our results are not necessarily comparable to previous studies that employ monotonic proxies for CSR (e.g. charitable donations; Ye and Zhang 2011). As a final caveat, our result may not be generalizable to different geographical regions and firms operating in the financial services sector.

Acknowledgments Open Access funding provided by Projekt DEAL.

Open Access This article is licensed under a Creative Commons Attribution 4.0 International License, which permits use, sharing, adaptation, distribution and reproduction in any medium or format, as long as you give appropriate credit to the original author(s) and the source, provide a link to the Creative Commons licence, and indicate if changes were made. The images or other third party material in this article are included in the article's Creative Commons licence, unless indicated otherwise in a credit line to the material. If material is not included in the article's Creative Commons licence and your intended use is not permitted by statutory regulation or exceeds the permitted use, you will need to obtain permission directly from the copyright holder. To view a copy of this licence, visit http://creativecommons.org/licen ses/by/4.0/.

\section{References}

Abdullah SN, Ismail KNIK, Nachum L (2016) Does having women on boards create value? The impact of societal perceptions and corporate governance in emerging markets. Strateg Manag J 37(3):466476. https://doi.org/10.1002/smj.2352

Ainsworth A, Corbett A, Satchell S (2018) Psychic dividends of socially responsible investment portfolios. J Asset Manag 19(3):179-190. https://doi.org/10.1057/s41260-017-0073-4

Amey M, Power G (2018) ESG investing and fixed income: The next new normal? https://www.pimco .com/en-us/insights/viewpoints/esg-investing-and-fixed-income-the-next-new-normal. Accessed 23 Apr 2020

Anderson RC, Mansi SA, Reeb DM (2004) Board characteristics, accounting report integrity, and the cost of debt. J Account Econ 37(3):315-342. https://doi.org/10.1016/j.jacceco.2004.01.004

Anderson SW, Dekker HC, Sedatole KL (2010) An empirical examination of goals and performance-togoal following the introduction of an incentive bonus plan with participative goal setting. Manag Sci 56(1):90-109. https://doi.org/10.1287/mnsc.1090.1088

Auer BR, Schuhmacher F (2016) Do socially (ir)responsible investments pay? New evidence from international ESG data. Q Rev Econ Financ 59:51-62. https://doi.org/10.1016/j.qref.2015.07.002

Barney J (1991) Firm resources and sustained competitive advantage. J Manag 17(1):99-120. https://doi. org/10.1177/014920639101700108

Barney JB, Ketchen DJ, Wright M (2011) The future of resource-based theory: revitalization or decline? J Manag 37(5):1299-1315. https://doi.org/10.1177/0149206310391805

Baum CF, Schaffer ME, Stillman S (2007) Enhanced routines for instrumental variables/generalized method of moments estimation and testing. Stata J 7(4):465-506. https://doi.org/10.1177/15368 67X0800700402 
Belghitar Y, Clark E, Deshmukh N (2014) Does it pay to be ethical? Evidence from the FTSE4Good. J Bank Financ 47:54-62. https://doi.org/10.1016/j.jbankfin.2014.06.027

Belkhir M (2009) Board of directors' size and performance in the banking industry. Int J Manag Financ 5(2):201-221. https://doi.org/10.1108/17439130910947903

Benlemlih M (2017) Corporate social responsibility and firm debt maturity. J Bus Ethics 144(3):491517. https://doi.org/10.1007/s10551-015-2856-1

Bradley M, Chen D (2015) Does board independence reduce the cost of debt? Financ Manag 44(1):1547. https://doi.org/10.1111/fima.12068

Brown HS, de Jong M, Levy DL (2009) Building institutions based on information disclosure: lessons from GRI's sustainability reporting. J Clean Prod 17(6):571-580. https://doi.org/10.1016/j.jclep ro.2008.12.009

Busch T, Friede G (2018) The robustness of the corporate social and financial performance relation: a second-order meta-analysis. Corp Soc Responsib Environ Manag 25(4):583-608. https://doi. org/10.1002/csr. 1480

Campbell K, Mínguez-Vera A (2008) Gender diversity in the boardroom and firm financial performance. J Bus Ethics 83(3):435-451. https://doi.org/10.1007/s10551-007-9630-y

Casey RJ, Grenier JH (2015) Understanding and contributing to the enigma of corporate social responsibility (csr) assurance in the United States. Audit: J Pract Theory 34(1):97-130. https://doi. org/10.2308/ajpt-50736

Chapple L, Humphrey JE (2014) Does board gender diversity have a financial impact? Evidence using stock portfolio performance. J Bus Ethics 122(4):709-723. https://doi.org/10.1007/s1055 1-013-1785-0

Chava S (2014) Environmental externalities and cost of capital. Manag Sci 60(9):2223-2247. https://doi. org/10.1287/mnsc.2013.1863

Cheng B, Ioannou I, Serafeim G (2014) Corporate social responsibility and access to finance. Strateg Manag J 35(1):1-23. https://doi.org/10.1002/smj.2131

Choi J, Wang H (2009) Stakeholder relations and the persistence of corporate financial performance. Strateg Manag J 30(8):895-907. https://doi.org/10.1002/smj.759

Chow CW (1982) The demand for external auditing: size, debt and ownership influences. Account Rev 57(2):272-291

Chuluun T, Prevost A, Puthenpurackal J (2014) Board ties and the cost of corporate debt. Financ Manag 43(3):533-568. https://doi.org/10.1111/fima.12047

Chung CY, Liu C, Wang K, Zykaj BB (2015) Institutional monitoring: evidence from the F-score. J Bus Financ Account 42(7-8):885-914. https://doi.org/10.1111/jbfa.12123

Cohen JR, Simnett R (2015) CSR and assurance services: a research agenda. Audit: J Pract Theory 34(1):59-74. https://doi.org/10.2308/ajpt-50876

Commission European (2014a) Corporate social responsibility: national public policies in the European Union. European Commission, Brussels

Commission European (2014b) Directive 2014/95/EU of the European Parliament and the Council. European Commission, Brussels

Commission European (2017) Analysis of European corporate bond markets. European Commission, Brussels

Commission European (2018) Action plan: financing sustainable growth. European Commission, Brussels

Consolandi C, Jaiswal-Dale A, Poggiani E, Vercelli A (2009) Global standards and ethical stock indexes: the case of the dow jones sustainability stoxx index. J Bus Ethics 87:185-197. https://doi. org/10.1007/s10551-008-9793-1

CSR Europe, GRI (2017). Member State implementation of Directive 2014/95/EU

Cummins JD, Dionne G, Harrington SE (eds) (1992) Huebner International Series on Risk, Insurance and Economic Security. Foundations of Insurance Economics. Springer, Dordrecht

Dass N, Kini O, Nanda V, Onal B, Wang J (2014) Board expertise: do directors from related industries help bridge the information gap? Rev Financ Stud 27(5):1533-1592. https://doi.org/10.1093/rfs/ hht071

Defond ML, Hann RN, Hu X (2005) Does the market value financial expertise on audit committees of boards of directors? J Account Res 43(2):153-193. https://doi.org/10.1111/j.1475679x.2005.00166.x

Derwall J, Koedijk K (2009) Socially responsible fixed-income funds. J Bus Financ Account 36(12):210-229. https://doi.org/10.1111/j.1468-5957.2008.02119.x 
Desender KA, Aguilera RV, Crespi R, García-cestona M (2013) When does ownership matter? Board characteristics and behavior. Strateg Manag J 34(7):823-842. https://doi.org/10.1002/smj.2046

Dhaliwal DS, Li OZ, Tsang A, Yang YG (2011) Voluntary nonfinancial disclosure and the cost of equity capital: the initiation of corporate social responsibility reporting. Account Rev 86(1):59-100. https ://doi.org/10.2308/accr.00000005

Dichev ID, Skinner DJ (2002) Large-sample evidence on the debt covenant hypothesis. J Account Res 40(4):1091-1123. https://doi.org/10.1111/1475-679X.00083

Dothan M (2006) Costs of financial distress and interest coverage ratios. J Financ Res 29(2):147-162. https://doi.org/10.1111/j.1475-6803.2006.00171.x

Dyck A, Lins KV, Roth L, Wagner HF (2019) Do institutional investors drive corporate social responsibility? International evidence. J Financ Econ 131(3):693-714. https://doi.org/10.1016/j.jfine co.2018.08.013

Eisenberg T, Sundgren S, Welis MT (1998) Larger board size and decreasing firm value in small firms. J Financ Econ 48:35-54

Equator Principles (2013) The Equator Principles: a financial industry benchmark for determining, assessing and managing environmental and social risk in projects. Equator Principles

European Commission (2020) Taxonomy: final report of the technical expert group on sustainable finance. European Commission, Brussels

Fair RC (1970) The estimation of simultaneous equation models with lagged endogenous variables and first order serially correlated errors. Econometrica 38(3):507-515. https://doi.org/10.2307/1909556

Fernández-Gago R, Cabeza-García L, Nieto M (2016) Corporate social responsibility, board of directors, and firm performance: an analysis of their relationships. Rev Manag Sci 10(1):85-104. https://doi. org/10.1007/s11846-014-0141-9

Ferreira MA, Matos P (2008) The colors of investors' money: the role of institutional investors around the world. J Financ Econ 88(3):499-533. https://doi.org/10.1016/j.jfineco.2007.07.003

Fombrun CJ, Gardberg NA, Sever JM (2000) The reputation quotientSM: a multi-stakeholder measure of corporate reputation. J Brand Manag 7(4):241-255. https://doi.org/10.1057/bm.2000.10

Freeman RE (1984) Strategic management: a stakeholder approach. Pitman Series in Business and Public Policy. Pitman, Boston

Friedman M (1970) The social responsibility of business is to increase its profits. The New York Times Magazine

Gangi F, Varrone N (2018) Screening activities by socially responsible funds: a matter of agency? J Clean Prod 197:842-855. https://doi.org/10.1016/j.jclepro.2018.06.228

Gasser SM, Rammerstorfer M, Weinmayer K (2017) Markowitz revisited: social portfolio engineering. Eur J Oper Res 258(3):1181-1190. https://doi.org/10.1016/j.ejor.2016.10.043

Gerwanski J, Kordsachia O, Velte P (2019) Determinants of materiality disclosure quality in integrated reporting: empirical evidence from an international setting. Bus Strategy Environ 18(382):750770. https://doi.org/10.1002/bse. 2278

Godfrey PC (2005) The relationship between corporate philanthropy and shareholder wealth: a risk management perspective. Acad Manag Rev 30(4):777-798. https://doi.org/10.5465/amr.2005.18378 878

Godfrey PC, Merrill CB, Hansen JM (2009) The relationship between corporate social responsibility and shareholder value: an empirical test of the risk management hypothesis. Strateg Manag J 30(4):425-445. https://doi.org/10.1002/smj.750

Godos-Díez J-L, Cabeza-García L, Alonso-Martínez D, Fernández-Gago R (2018) Factors influencing board of directors' decision-making process as determinants of CSR engagement. Rev Manag Sci 12(1):229-253. https://doi.org/10.1007/s11846-016-0220-1

Gong G, Xu S, Gong X (2018) On the value of corporate social responsibility disclosure: an empirical investigation of corporate bond issues in china. J Bus Ethics 150(1):227-258. https://doi. org/10.1007/s10551-016-3193-8

Goranova ML, Priem RL, Ndofor HA, Trahms CA (2017) Is there a "dark side" to monitoring? Board and shareholder monitoring effects on M\&A performance extremeness. Strateg Manag J 38(11):22852297. https://doi.org/10.1002/smj.2648

Goss A, Roberts GS (2011) The impact of corporate social responsibility on the cost of bank loans. J Bank Finance 35(7):1794-1810. https://doi.org/10.1016/j.jbankfin.2010.12.002

Grant RM (1991) The resource-based theory of competitive advantage: implications for strategy formulation. Calif Manag Rev 33(3):114-135. https://doi.org/10.2307/41166664 
Güner BA, Malmendier U, Tate G (2008) Financial expertise of directors. J Financ Econ 88(2):323-354. https://doi.org/10.1016/j.jineco.2007.05.009

Hansen LP (1982) Large sample properties of generalized method of moments estimators. Econometrica 50(4):1029-1051. https://doi.org/10.2307/1912775

Harjoto MA, Jo H (2011) Corporate governance and CSR nexus. J Bus Ethics 100(1):45-67. https://doi. org/10.1007/s10551-011-0772-6

Hart SL (1995) A Natural-Resource-Based View of the Firm. The Academy of Management Review 20(4):986-1014. https://doi.org/10.2307/258963

Hill CWL, Jones TM (1992) Stakeholder-agency theory. J Manage Stud 29(2):131-154. https://doi. org/10.1111/j.1467-6486.1992.tb00657.x

Hoepner A, Oikonomou I, Scholtens B, Schröder M (2016) The effects of corporate and country sustainability characteristics on the cost of debt: an international investigation. J Bus Financ Account 43(1-2):158-190. https://doi.org/10.1111/jbfa.12183

Hox JJ (2010) Multilevel analysis: techniques and applications. Routledge, London

Huang S, Hilary G (2018) Zombie board: board tenure and firm performance. J Account Res 56(4):12851329. https://doi.org/10.1111/1475-679X.12209

Hur W-M, Kim H, Woo J (2014) How CSR leads to corporate brand equity: mediating mechanisms of corporate brand credibility and reputation. J Bus Ethics 125(1):75-86. https://doi.org/10.1007/ s10551-013-1910-0

IFC (2015) A guide to corporate governance practices in the European Union. https://www.ifc.org/ wps/wcm/connect/506d49a2-3763-4fe4-a783-5d58e37b8906/CG_Practices_in_EU_Guide .pdf?MOD=AJPERES\&CVID=kNmxTtG. Accessed 23 Apr 2020

Ingley CB, van der Walt NT (2004) Corporate governance, institutional investors and conflicts of interest. Corp Govern Int Rev 12(4):534-551. https://doi.org/10.1111/j.1467-8683.2004.00392.x

Ioannou I, Serafeim G (2015) The impact of corporate social responsibility on investment recommendations: analysts' perceptions and shifting institutional logics. Strateg Manag J 36(7):1053-1081. https://doi.org/10.1002/smj.2268

Jenkins H (2009) A 'business opportunity' model of corporate social responsibility for smalland medium-sized enterprises. Bus Ethics: Eu Rev 18(1):21-36. https://doi.org/10.111 $1 / \mathrm{j} .1467-8608.2009 .01546 . x$

Jensen MC, Meckling WH (1976) Theory of the firm: managerial behavior, agency costs and ownership structure. J Financ Econ 3(4):305-360. https://doi.org/10.1016/0304-405X(76)90026-X

Jensen MC, Smith CW (eds) (1985) Recent advances in corporate finance. Stockholder, manager, and creditor interests: applications of agency theory. R.D. Irwin, Homewood

Jianakoplos NA, Bernasek A (1998) Are women more risk averse? Econ Inq 36(4):620-630. https://doi. org/10.1111/j.1465-7295.1998.tb01740.x

Jones TM (1995) Instrumental stakeholder theory: a synsthesis of ethics and economics. Acad Manag Rev 20(2):404-437. https://doi.org/10.5465/amr.1995.9507312924

Jung J, Herbohn K, Clarkson P (2018) Carbon risk, carbon risk awareness and the cost of debt financing. J Bus Ethics 150(4):1151-1171. https://doi.org/10.1007/s10551-016-3207-6

Kim M, Surroca J, Tribó JA (2014) Impact of ethical behavior on syndicated loan rates. J Bank Finance 38:122-144. https://doi.org/10.1016/j.jbankfin.2013.10.006

Kleibergen F, Paap R (2006) Generalized reduced rank tests using the singular value decomposition. J Econom 133(1):97-126. https://doi.org/10.1016/j.jeconom.2005.02.011

Kor YY (2006) Direct and interaction effects of top management team and board compositions on R\&D investment strategy. Strateg Manag J 27(11):1081-1099. https://doi.org/10.1002/smj.554

KPMG (2017) The road ahead: The KPMG survey of corporate responsibility reporting 2017. https:// home.kpmg/xx/en/home/insights/2017/10/the-kpmg-survey-of-corporate-responsibility-reporting2017.html. Accessed 23 Apr 2020

Kudłak R, Szôcs I, Krumay B, Martinuzzi A (2018) The future of CSR—selected findings from a Europewide delphi study. J Clean Prod 183:282-291. https://doi.org/10.1016/j.jclepro.2018.02.119

La Rosa F, Liberatore G, Mazzi F, Terzani S (2018) The impact of corporate social performance on the cost of debt and access to debt financing for listed European non-financial firms. Eur Manag $\mathrm{J}$ 36(4):519-529. https://doi.org/10.1016/j.emj.2017.09.007

Lins VN, Servaes H, Tamayo A (2017) Social capital, trust, and firm performance: the value of corporate social responsibility during the financial crisis. J Financ 72(4):1785-1824. https://doi.org/10.1111/ jofi.12505 
López MV, Garcia A, Rodriguez L (2007) Sustainable development and corporate performance: a study based on the dow jones sustainability index. J Bus Ethics 75(3):285-300. https://doi.org/10.1007/ s10551-006-9253-8

Macve R, Chen X (2010) The “equator principles": a success for voluntary codes? Account Audit Acc J 23(7):890-919. https://doi.org/10.1108/09513571011080171

Magness V (2006) Strategic posture, financial performance and environmental disclosure. Account Audit Acc J 19(4):540-563. https://doi.org/10.1108/09513570610679128

Majoch AAA, Hoepner AGF, Hebb T (2017) Sources of stakeholder salience in the responsible investment movement: why do investors sign the principles for responsible investment? J Bus Ethics 140(4):723-741. https://doi.org/10.1007/s10551-016-3057-2

Margolis JD, Walsh JP (2003) Misery loves companies: rethinking social initiatives by business. Adm Sci Q 48(2):268-305. https://doi.org/10.2307/3556659

Margolis JD, Elfenbein HA, Walsh JP (2009) Does it pay to be good...And does it matter? A metaanalysis of the relationship between corporate social and financial performance. Working Paper. Advance online publication. https://doi.org/10.2139/ssrn.1866371

Maroun W (2018) A conceptual model for understanding corporate social responsibility assurance practice. J Bus Ethics 17(2):187-209. https://doi.org/10.1007/s10551-018-3909-z

Mayers D, Smith CW (1982) On the corporate demand for insurance. J Bus 55(2):281-296

McGuire JB, Sundgren A, Schneeweis T (1988) Corporate social responsibility and firm financial performance. Acad Manag J 31(4):854-872. https://doi.org/10.5465/256342

McWilliams A, Siegel D (2000) Corporate social responsibility and financial performance: correlation or misspecification? Strateg Manag J 21(5):603-609. https://doi.org/10.1002/(SICI)10970266(200005)21:5\%3c603:AID-SMJ101\%3e3.0.CO;2-3

McWilliams A, Siegel D (2001) Corporate Social Responsibility: a Theory of the Firm Perspective. Acad Manag Rev 26(1):117-127. https://doi.org/10.5465/amr.2001.4011987

Menz K-M (2010) Corporate social responsibility: is it rewarded by the corporate bond market? A critical note. J Bus Ethics 96(1):117-134. https://doi.org/10.1007/s10551-010-0452-y

Merton RC (1974) On the pricing of corporate debt: the risk structure of interest rates. J F 29(2):449470. https://doi.org/10.1111/j.1540-6261.1974.tb03058.x

Minton BA, Taillard JP, Williamson R (2014) Financial expertise of the board, risk taking, and performance: evidence from bank holding companies. J Financ Quant Anal 49(02):351-380. https ://doi.org/10.1017/S0022109014000283

Montiel I, Delgado-Ceballos J (2014) Defining and measuring corporate sustainability. Organization \& Environment 27(2):113-139. https://doi.org/10.1177/1086026614526413

Morris RD (1987) Signalling, agency theory and accounting policy choice. Acc Bus Res 18(69):4756. https://doi.org/10.1080/00014788.1987.9729347

O'Sullivan N, O'Dwyer B (2015) The structuration of issue-based fields: social accountability, social movements and the Equator Principles issue-based field. Acc Organ Soc 43:33-55. https://doi. org/10.1016/j.aos.2015.03.008

O’Dwyer B, Owen D (2007) Seeking stakeholder-centric sustainability assurance. J Corp Citiz 2007(25):77-94. https://doi.org/10.9774/GLEAF.4700.2007.sp.00009

Oehmichen J, Schrapp S, Wolff M (2017) Who needs experts most? Board industry expertise and strategic change-a contingency perspective. Strateg Manag J 38(3):645-656. https://doi. org/10.1002/smj.2513

Oikonomou I, Brooks C, Pavelin S (2014) The effects of corporate social performance on the cost of corporate debt and credit ratings. Financ Rev 49(1):49-75. https://doi.org/10.1111/fire.12025

Orlitzky M, Schmidt FL, Rynes SL (2003) Corporate social and financial performance: a meta-analysis. Org Stud 24(3):403-441. https://doi.org/10.1177/0170840603024003910

O'Sullivan N, O'Dwyer B (2009) Stakeholder perspectives on a financial sector legitimation process. Account Audit Account J 22(4):553-587. https://doi.org/10.1108/09513570910955443

Pava ML, Krausz J (1996) The association between corporate social-responsibility and financial performance: the paradox of social cost. J Bus Ethics 15(3):321-357. https://doi.org/10.1007/ BF00382958

Piotroski JD (2000) Value investing: the use of historical financial statement information to separate winners from losers. J Account Res 38:1. https://doi.org/10.2307/2672906

Prencipe A, Bar-Yosef S (2011) Corporate governance and earnings management in family-controlled companies. J Acc Audit Financ 26(2):199-227. https://doi.org/10.1177/0148558X11401212

PRI (2017) Shifting perceptions: esg, credit risk and ratings: part 1: the state of play: PRI 
PRI (2018) Shifting perceptions: esg, credit risk and ratings: part 2: exploring the disconnects: PRI

Riedl A, Smeets P (2017) Why do investors hold socially responsible mutual funds? J Financ 72(6):2505-2550. https://doi.org/10.1111/jofi.12547

Servaes H, Tamayo A (2013) The impact of corporate social responsibility on firm value: the role of customer awareness. Manag Sci 59(5):1045-1061. https://doi.org/10.1287/mnsc.1120.1630

Sethi SP, Martell TF, Demir M (2017) Enhancing the role and effectiveness of corporate social responsibility (csr) reports: the missing element of content verification and integrity assurance. J Bus Ethics 144(1):59-82. https://doi.org/10.1007/s10551-015-2862-3

Sharfman MP, Fernando CS (2008) Environmental risk management and the cost of capital. Strateg Manag J 29(6):569-592. https://doi.org/10.1002/smj.678

Shaukat A, Trojanowski G (2018) Board governance and corporate performance. J Bus Financ Acc 45(12):184-208. https://doi.org/10.1111/jbfa.12271

Simnett R, Vanstraelen A, Chua WF (2009) Assurance on sustainability reports: an international comparison. Acc Rev 84(3):937-967. https://doi.org/10.2308/accr.2009.84.3.937

Spence M (1973) Job market signaling. Q J Econ 87(3):355-374. https://doi.org/10.2307/1882010

Stellner C, Klein C, Zwergel B (2015) Corporate social responsibility and Eurozone corporate bonds: the moderating role of country sustainability. J Bank Financ 59:538-549. https://doi.org/10.1016/j. jbankfin.2015.04.032

Stohs MH, Mauer DC (1996) The determinants of corporate debt maturity structure. J Bus 69(3):279-312

Torgusa N, O'Donohue W, Hecker R (2012) Capabilities, proactive CSR and financial performance in SMEs: empirical evidence from an australian manufacturing industry sector. J Bus Ethics 109:483500. https://doi.org/10.1007/s10551-011-1141-1

Udayasankar K (2008) Corporate social responsibility and firm size. J Bus Ethics 83(2):167-175. https:// doi.org/10.1007/s10551-007-9609-8

Velte P (2017) Do women on board of directors have an impact on corporate governance quality and firm performance? A literature review. Int J Sustain Strateg Manag 5(4):302-346. https://doi. org/10.1504/IJSSM.2017.10010121

Velte P, Stawinoga M (2017) Empirical research on corporate social responsibility assurance (CSRA): a literature review. J Bus Econ 87(8):1017-1066. https://doi.org/10.1007/s11573-016-0844-2

Waddock SA, Graves SB (1997) The corporate social performance-financial performance link. Strateg Manag J 18(4):303-319. https://doi.org/10.1002/(SICI)1097-0266(199704)18:4\%3c303:AIDSMJ869\%3e3.0.CO;2-G

Wang H, Choi J, Li J (2008) Too little or too much? Untangling the relationship between corporate philanthropy and firm financial performance. Organ Sci 19(1):143-159. https://doi.org/10.1287/ orsc. 1070.0271

Wang C, Xie F, Zhu M (2015) Industry expertise of independent directors and board monitoring. J Financ Quant Anal 50(05):929-962. https://doi.org/10.1017/S0022109015000459

Wang Q, Dou J, Jia S (2016) A meta-analytic review of corporate social responsibility and corporate financial performance. Bus Soc 55(8):1083-1121. https://doi.org/10.1177/0007650315584317

Weber M (2008) The business case for corporate social responsibility: a company-level measurement approach for CSR. Eur Manag J 26(4):247-261. https://doi.org/10.1016/j.emj.2008.01.006

Weber O (2018) Financial sector sustainability regulations and voluntary codes of conduct. In: Walker T, Kibsey SD, Crichton R (eds) Palgrave studies in sustainable business in association with Future Earth, vol 17. Palgrave Macmillan, Cham, pp 383-404

Wernerfelt B (1984) A resource-based view of the firm. Strateg Manag J 5(2):171-180. https://doi. org/10.1002/smj. 4250050207

Willis CAA (2003) The role of the global reporting initiative's sustainability reporting guidelines in the social screening of investments. J Bus Ethics 43(3):233-237. https://doi.org/10.1023/A:10229 58618391

Wooldridge JM (2007) Econometric analysis of cross section and panel data. MIT Pr, London

Ye K, Zhang R (2011) Do lenders value corporate social responsibility? Evidence from China. J Bus Ethics 104(2):197-206. https://doi.org/10.1007/s10551-011-0898-6

Zhao M (2012) CSR-based political legitimacy strategy: managing the state by doing good in China and Russia. J Bus Ethics 111(4):439-460. https://doi.org/10.1007/s10551-012-1209-6

Publisher's Note Springer Nature remains neutral with regard to jurisdictional claims in published maps and institutional affiliations. 